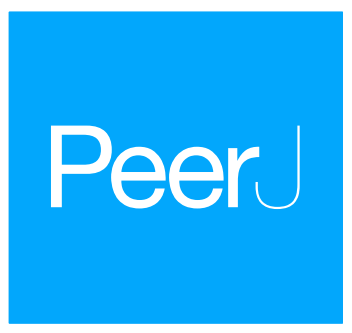

\title{
Integrative taxonomic reassessment of Odontophrynus populations in Argentina and phylogenetic relationships within Odontophrynidae (Anura)
}

\author{
Adolfo Ludovico Martino ${ }^{1,2}$, Jonas Maximilian Dehling ${ }^{2}$ and \\ Ulrich Sinsch ${ }^{2}$ \\ ${ }^{1}$ Department of Ecology, National University of Rio Cuarto, Rio Cuarto (Cordoba), Argentina \\ ${ }^{2}$ Department of Biology, Institute of Integrated Sciences, University of Koblenz-Landau, \\ Koblenz, Germany
}

\section{ABSTRACT}

Amphibians are the most vulnerable vertebrates to biodiversity loss mediated by habitat destruction, climate change and diseases. Informed conservation management requires improving the taxonomy of anurans to assess reliably the species' geographic range. The genus Odontophrynus that is geographically refined to Argentina, Bolivia, Brazil, Uruguay and Paraguay includes currently 12 nominal species with many populations of uncertain taxonomic assignment and subsequently unclear geographic ranges. In this study, we applied integrative taxonomic methods combining molecular (mitochondrial 16S gene), allozyme, morphological and bioacoustic data to delimit species of the genus Odontophrynus sampled from throughout Argentina where most species occur. The combined evidence demonstrates one case of cryptic diversity and another of overestimation of species richness. The populations referred to as O. americanus comprise at least three species. In contrast, O. achalensis and O. barrioi represent junior synonyms of the phenotypically plastic species O. occidentalis. We conclude that each of the four species occurring in Argentina inhabits medium to large areas. The Red List

Submitted 8 October 2018 Accepted 20 January 2019 Published 25 February 2019

Corresponding author Ulrich Sinsch, sinsch@uni-koblenz.de

Academic editor

Joseph Gillespie

Additional Information and Declarations can be found on page 25

DOI 10.7717/peerj.6480

(c) Copyright

2019 Martino et al.

Distributed under

Creative Commons CC-BY 4.0

OPEN ACCESS classification is currently "Least Concern". We also propose a phylogenetic hypothesis for the genus and associated genera Macrogenioglottus and Proceratophrys (Odontophrynidae).

Subjects Biodiversity, Evolutionary Studies, Taxonomy, Zoology

Keywords Integrative taxonomy, Allozymes, Advertisement call, Species delimitation, Macrogenioglottus, Odontophrynus, Morphometry, 16S rRNA sequences, Proceratophrys

\section{INTRODUCTION}

Distribution pattern of Neotropical amphibian diversity is not well understood because of incomplete information on taxonomy and distribution (Vieites et al., 2009; Winter et al., 2016). Yet amphibians are of high conservation concern, with almost $43 \%$ the currently known species being globally threatened and another $25 \%$ data deficient (Stuart et al., 2004). Taxonomic uncertainty stems partially from the prevalence of the morphospecies concept in most original descriptions of amphibian species (Frost, 2018). 
Morphological characters alone often fail to differentiate among closely related species due to the conservatism in the morphological evolution of anurans (Elmer, Dávila \& Lougheed, 2007; Vences et al., 2010; Kaefer et al., 2013; Rojas et al., 2018). Advertisement calls act as powerful tools of premating isolation and can reveal morphologically cryptic species in sympatry, but in allopatry distinct species may give almost identical calls (Schneider \& Sinsch, 2007; Köhler et al., 2017; Vacher et al., 2017). Delimiting species solely based on genetic distances obtained by barcoding approaches may inflate real species numbers by overestimating the taxonomic importance of intraspecific genetic structuring (Sukumaran \& Knowles, 2017). Therefore, species delimitation should attempt to unite several lines of evidence to provide robust taxonomic hypotheses (Dayrat, 2005; Padial \& De La Riva, 2010; Rojas et al., 2018).

South American anurans provide several examples for morphologically highly conserved genera in which integrative taxonomy led to reliable species delimitation and subsequent conservation priorities (De Magalhães et al., 2018; Fouquet et al., 2018; Von May, Lehr \& Rabosky, 2018). The semi fossorial toads of the genus Odontophrynus pose a similar challenge because all original species descriptions are solely based on morphology and often too ambiguous for a reliable species distinction (Duméril \& Bibron, 1841; Berg, 1896; Cei, Ruiz \& Beçak, 1982; Di Tada et al., 1984; Cei, 1985; Martino \& Sinsch, 2002; Rosset et al., 2006, 2007; Rosset, 2008; Caramaschi \& Napoli, 2012; Rocha et al., 2017). Extant populations are currently assigned to 12 species that are placed into three phenetic groups based on overall morphological similarities, except for O. salvatori that is possibly a misplaced Proceratophrys species (Caramaschi, 1996; Amaro, Pavan \& Rodrigues, 2009; Caramaschi \& Napoli, 2012; Frost, 2018).

The O. americanus group includes five nominal species (O. americanus, O. cordobae, O. juquinha, O. lavillai and O. maisuma), the O. occidentalis group three nominal species (O. achalensis, O. barrioi and O. occidentalis), and the O. cultripes group again three nominal species (O. carvalhoi, O. cultripes and O. monachus). Odontophrynus toads inhabit a latitudinal range of $5^{\circ} \mathrm{S}-41^{\circ} \mathrm{S}$ east of the Andes covering an altitudinal range from sea level to montane valleys of about 2,200 $\mathrm{m}$ above sea level (Turazzini, Taglioretti \& Gomez, 2016; Santos-Silva et al., 2017).

The reliability of taxonomic assignment of populations to the currently recognized species is hampered by the overall similarity of external morphology, and assumed geographic ranges bear a high degree of uncertainty. Therefore, the status in the IUCN Red List of Threatened Species and resulting conservation needs are at least debatable, with seven species considered as "Least Concern," one as "Vulnerable" and five as "Data Deficient" (IUCN, 2018). The three disjunct areas inhabited by the tetraploid O. americanus may indicate the presence of cryptic species (Rosset et al., 2006). The Odontophrynus sp. of the Sierra de San Luis may or not be conspecific with O. achalensis described from the Sierras de Cordoba (Di Tada et al., 1984). Diploid O. americanus-like populations reported from the vicinity of the disjunct O. americanus ranges have been recently described as three distinct species, O. cordobae in Central Argentina (Martino \& Sinsch, 2002), O. maisuma in coastal Uruguay and Brazil (Rosset, 2008) and O. juquinha in Minas Gerais, Brazil (Rocha et al., 2017). 
It remains controversial, if diploids of the O. americanus group derived from tetraploids or tetraploids several times independently from diploids (Beçak \& Beçak, 1974; Beçak, 2014). With respect to these issues and the validity of the phenetic groups within Odontophrynus, the most recent molecular phylogeny of Odontophrynus is inconclusive being based on only three of the 12 nominal taxa (Dias et al., 2013). Earlier phylogenies proposed by Amaro, Pavan \& Rodrigues (2009), Pyron \& Wiens (2011) as well as the recent one by Feng et al. (2017) agree in that Odontophrynidae is monophyletic and that Macrogenioglottus and Odontophrynus are sister taxa.

Consequently, a reliable taxonomic and geographic delimitation of Odontophrynus species requires an integrative approach critically evaluating information available on genetic differentiation and phenotypic plasticity. In this study we adopt the consensus protocol for integrative taxonomy to delimit species (Padial et al., 2010). Geographically, we focus on Argentina where most currently recognized Odontophrynus species and several populations of still undetermined taxonomic status occur. The character complexes included in the re-assessment of taxa are quantitative morphometrics, advertisement call features, allozyme differentiation and partial mitochondrial 16S rRNA sequences, all providing meaningful taxonomic information. Data refer to 34 populations, among them those at the type localities for reference. Sites of sympatry (O. americanus/ O. occidentalis, O. cordobae/O. occidentalis) are contrasted with those in narrow contact zones (O. americanus/O. cordobae, O. achalensis/O. occidentalis) and sites of allopatry. Additional data on the molecular Odontophrynus diversity in Brazil are used for a broader phylogenetic view on Odontophrynidae (Amaro, Pavan \& Rodrigues, 2009; Dias et al., 2013; Lyra, Haddad \& De Azeredo-Espin, 2017). Specifically, we test the following hypotheses: (1) Phenotypic plasticity within and among Odontophrynus taxa is associated with corresponding genetic differentiation; (2) The phenetic groups within Odontophrynus represent distinct phylogenetic lineages; (3) The current Red List classification does not reflect the risks upon each species.

\section{MATERIALS AND METHODS}

\section{Study area and field sampling}

We identified and sampled 34 local populations of toads pertaining to the genus Odontophrynus in Argentina (Table S1). The type localities of the nominal taxa O. achalensis Di Tada et al., 1984 (Pampa de Achala, Cordoba province), O. barrioi Cei, Ruiz, and Beçak, 1982 (Aguadita springs, Sierra de Famatina, La Rioja province), O. cordobae Martino \& Sinsch, 2002 (Villa General Belgrano, Cordoba province) and O. lavillai Cei, 1985 (Villa de la Punta, Santiago del Estero province) were sampled to obtain topotypical individuals for taxonomic comparison. Unfortunately, the exact type localities of the most wide-spread species O. americanus (Duméril \& Bibron, 1841) and O. occidentalis (Berg, 1896) are unknown because the original descriptions only state that the holotype of O. americanus was "sent from Buenos Aires" and that the holotype of O. occidentalis was collected in "Arroyo Agrio" in the Neuquén province (Frost, 2018). According to Lescure et al. (2002), the type locality of O. americanus is probably "rives du Rio Negro, Patagonie" in the Río Negro province (Argentina; D’Orbigny, 1847) at the 
southernmost part of the current geographical range. Still, populations of tetraploid $O$. americanus were readily distinguished from those of the diploid taxa by erythrocyte size (Rosset et al., 2006; Grenat, Salas \& Martino, 2009). Populations of uncertain taxonomic assignment were tentatively referred to as $O$. cf. achalensis (Locality: La Carolina, San Luis province) or O. cf. barrioi (Localities: Aguada de Molle, Huerta de Guachi, San Juan province; Table S1). Material and data collected at the study sites were: (1) blood smears for ploidy assessment; (2) adult specimens for morphometric measurements, (3) records of advertisement calls, (4) muscle and liver homogenates for allozyme analyses and (5) alcohol preserved tissue for phylogenetic analyses (partial sequences of the mitochondrial 16S rRNA gene). The carcasses of specimens studied were deposited in museum collections; Table S1. The Córdoba Environment Agency (A.C.A.S.E.), Environmental Secretary of Córdoba Government (A01-2013), authorized our study and issued research and collecting permits.

\section{Morphological data}

In a first step, presumed ploidy (diploid/tetraploid) was verified by measuring the erythrocyte size, which correlates with the DNA content. Smears of fresh blood were airdried and light-microscopically examined at a magnification of $1,000 \times$ using an OLYMPUS BX50 following the procedures described in Grenat, Salas \& Martino (2009). Specimens were euthanized, tissues sampled and carcasses preserved in $4 \%$ formaldehyde. Use of vertebrate animals was approved by the Ethics Committee Comité de Ética de la Investigación (COEDI) of the Universidad Nacional de Rio Cuarto. (https://www.unrc.edu.ar/unrc/coedi/index.html). The investigation was conducted according to the state law "Protection and Conservation of Wild Fauna" (Argentina National Law $\mathrm{N}^{\circ}$ 22.421) and the Ethical Committee of Investigation of the National University of Río Cuarto ( $\left.\mathrm{N}^{\circ} 38 / 11\right)$. The external morphology of 256 specimens was described quantitatively by measuring 15 morphometric distances (to the nearest $0.1 \mathrm{~mm}$; Martino \& Sinsch, 2002):

(1) Snout-vent length (SVL); (2) maximal head width (HW); (3) head length (HL);

(4) snout-eye distance (SED); (5) internarinal distance (IND); (6) interocular distance (IOD);

(7) eye-narinal distance (END); (8) rostronarinal distance (RND); (9) eye diameter (ED);

(10) humerus length (HL); (11) length of 3rd finger (F3L); (12) femur length (FL); (13) tibia length (TL); (14) foot length (FOL); (15) length of 4th toe (T4L). All measurements were taken by the first author. Morphometric raw data are available in Dataset S1.

Each variable was standardized by subtracting the sample mean and dividing by the sample standard deviation. The matrix of standardized variables was subjected to a principal component analysis with a fixed number of three PCs extracted. By this means, we explored the morphometric variability independent of taxonomic assignment and reduced the information to statistically unrelated factors. PC1 represents size-related features, PC2 and PC3 shape-related ones. Separate PCAs were run on the taxa of the phenetic groups. Assignment of populations to a phenetic group was based on the advertisement call structure (O. americanus-group: simple pulsed calls;

O. occidentalis-group: complex calls consisting of several pulse groups; Salas \& Di Tada, 1994; Martino \& Sinsch, 2002). The morphospace built by three PC-axes was used to 
evaluate partitioning among taxa. A discriminant analysis (Procedure: backward selection) with a priori taxon assignment was applied to quantify the partitioning of morphospace for each phenetic group. Removal of one or more morphometric variables is based on an $F$-to-remove test. If the least significant variable has an $F$-value less than 4.0 , it will be removed from the model. We used the discriminant analyses to assess the magnitude of correct taxon classification for the individuals of each predefined group. Due to the partial sympatry among species of the $O$. occidentalis group we tested for clinal variation of PCs along latitudinal and altitudinal gradients by a multiple regression analysis (Procedure: backward selection at $F=4.0$ ). Significance level was set to $\alpha=0.05$. All calculations were performed using the statistical package statgraphics centurion, version XVIII (Statpoint Inc., Warrenton, Virginia, USA).

\section{Bioacoustic data}

Advertisement calls given by 302 individuals (series of 11-116 calls per individual) were recorded in the field using a DAT recorder Sony TCD- $100^{\odot}$ with stereo microphone ECM-MS907 Sony ${ }^{\odot}$ and tapes TDK DA-RGX $60^{\odot}$ (Table 1). Ambient temperature (to the nearest $0.5^{\circ} \mathrm{C}$ ) was registered at the individual calling sites (usually shallow water near shore) immediately after recording. Short advertisement call series are available as Audio S1-S8. Whenever possible, specimens were collected to obtain tissue samples and for morphometric measurements. Oscillograms, sonograms and power spectra of the call series were prepared with the Medav Mosip 3000 Signal Processing System or the PC program Adobe Audition 1.0. Each call series was characterized by nine parameters which were measured in three calls per series (terminology and procedure according to Martino \& Sinsch (2002) and Schneider \& Sinsch (2007)): (1) call duration (ms);

(2) number of pulse groups per call $(N)$; (3) duration of pulse group (ms); (4) interval between pulse groups; (5) pulses per pulse group $(N)$; (6) pulse duration (ms); (7) interpulse interval (ms); (8) pulse rate (pulses/s); (9) dominant frequency $(\mathrm{Hz})$. Bioacoustic raw data are available in Dataset S2.

The arithmetic means of these call parameters were calculated for each series (=individual) and used for further analyses. Thus, the basic data set describing the advertisement calls of the populations studied consisted of 10 variables (nine call parameters and the corresponding ambient temperature) with $N=302$ observations. As several call variables co-vary with ambient temperature, we calculated linear regression models of call parameter vs. temperature and used the standardized residuals to obtain a temperature-adjusted data set for further analysis. Analogous to the treatment of morphometric data, a principal component analysis was run on call data subsets of populations with homologous call structure (simple calls with six variables vs. complex calls with nine variables) to explore the bioacoustic differentiation among the taxa of each phenetic group. The three PCs explaining most of the variance were extracted to describe the sound space utilized by Odontophrynus and its partitioning among taxa. Moreover, a discriminant analysis (procedure: backward selection at $F=4.0$ ) was applied on standardized call variables to quantify the partitioning of among-taxon sound space.

We used the discriminant analyses to assess the magnitude of correct taxon classification for 
Table 1 Principal component analyses of morphometric and call data sets.

(A) Individuals of the O. americanus-group

\begin{tabular}{|c|c|c|c|c|c|c|c|}
\hline \multirow{2}{*}{$\begin{array}{l}\text { Morphometric } \\
\text { variables with } \\
N=151 \\
\text { observations }\end{array}$} & \multirow{2}{*}{$\begin{array}{l}\text { PC1 } \\
\text { Eigenwert: } \\
\text { 9.71 Variance } \\
\text { explained: } 64.7 \%\end{array}$} & \multirow{2}{*}{$\begin{array}{l}\text { PC2 } \\
\text { Eigenwert: } \\
0.97 \text { Variance } \\
\text { explained: } 6.5 \%\end{array}$} & \multirow{2}{*}{$\begin{array}{l}\text { PC3 } \\
\text { Eigenwert: } \\
0.90 \text { Variance } \\
\text { explained: } 6.0 \%\end{array}$} & \multirow{2}{*}{$\begin{array}{l}\text { Call variables } \\
\text { with } N=227 \\
\text { observations }\end{array}$} & \multirow{2}{*}{$\begin{array}{l}\text { PC1 } \\
\text { Eigenwert: } \\
2.70 \text { Variance } \\
\text { explained: } 45.0 \%\end{array}$} & \multirow{2}{*}{$\begin{array}{l}\text { PC2 } \\
\text { Eigenwert: } \\
1.48 \text { Variance } \\
\text { explained: } 24.7 \%\end{array}$} & \multirow{2}{*}{$\begin{array}{l}\text { PC3 } \\
\text { Eigenwert: } \\
0.94 \text { Variance } \\
\text { explained: } 15.6 \%\end{array}$} \\
\hline & & & & & & & \\
\hline SVL & 0.289 & -0.129 & 0.025 & Call duration & 0.286 & 0.497 & 0.508 \\
\hline HW & 0.295 & -0.103 & 0.096 & Pulses per call & -0.351 & 0.138 & 0.738 \\
\hline $\mathrm{HL}$ & 0.227 & -0.182 & 0.348 & Pulse duration & 0.454 & 0.352 & -0.229 \\
\hline SED & 0.226 & -0.510 & -0.067 & $\begin{array}{l}\text { Interpulse } \\
\text { duration }\end{array}$ & 0.486 & -0.342 & 0.229 \\
\hline IND & 0.221 & 0.067 & -0.364 & Pulse rate & -0.589 & 0.060 & -0.147 \\
\hline IOD & 0.165 & -0.039 & 0.754 & $\begin{array}{l}\text { Dominant } \\
\text { frequency }\end{array}$ & 0.074 & -0.700 & 0.266 \\
\hline END & 0.258 & -0.047 & 0.106 & & & & \\
\hline RND & 0.220 & -0.463 & -0.303 & & & & \\
\hline ED & 0.246 & -0.269 & -0.150 & & & & \\
\hline HL & 0.296 & 0.144 & -0.080 & & & & \\
\hline FL & 0.278 & 0.216 & -0.056 & & & & \\
\hline $\mathrm{TL}$ & 0.298 & 0.162 & 0.092 & & & & \\
\hline FOL & 0.289 & 0.218 & -0.026 & & & & \\
\hline F3L & 0.264 & 0.371 & -0.134 & & & & \\
\hline T4L & 0.261 & 0.324 & -0.047 & & & & \\
\hline
\end{tabular}

(B) Individuals of the O. occidentalis-group

\begin{tabular}{|c|c|c|c|c|c|c|c|}
\hline \multirow{2}{*}{$\begin{array}{l}\text { Morphometric } \\
\text { variables with } \\
N=105 \\
\text { observations }\end{array}$} & \multirow{2}{*}{$\begin{array}{l}\text { PC1 } \\
\text { Eigenwert: } \\
10.53 \text { Variance } \\
\text { explained: } 70.2 \%\end{array}$} & \multirow{2}{*}{$\begin{array}{l}\text { PC2 } \\
\text { Eigenwert: } \\
0.79 \text { Variance } \\
\text { explained: } 5.3 \%\end{array}$} & \multirow{2}{*}{$\begin{array}{l}\text { PC3 } \\
\text { Eigenwert: } \\
0.69 \text { Variance } \\
\text { explained: } 4.6 \%\end{array}$} & \multirow{2}{*}{$\begin{array}{l}\text { Call variables } \\
\text { with } N=75 \\
\text { observations }\end{array}$} & \multirow{2}{*}{$\begin{array}{l}\text { PC1 } \\
\text { Eigenwert: } \\
\text { 3.41 Variance } \\
\text { explained: } 37.9 \%\end{array}$} & \multirow{2}{*}{$\begin{array}{l}\text { PC2 } \\
\text { Eigenwert: } \\
1.99 \text { Variance } \\
\text { explained: } 22.1 \%\end{array}$} & \multirow{2}{*}{$\begin{array}{l}\text { PC3 } \\
\text { Eigenwert: } \\
1.62 \text { Variance } \\
\text { explained: } 18.0 \%\end{array}$} \\
\hline & & & & & & & \\
\hline SVL & 0.286 & -0.001 & 0.010 & Call duration & 0.397 & -0.079 & 0.429 \\
\hline HW & 0.291 & -0.009 & 0.020 & $\begin{array}{l}\text { Pulse groups } \\
\text { per call }\end{array}$ & 0.390 & -0.179 & 0.422 \\
\hline $\mathrm{HL}$ & 0.222 & -0.286 & 0.551 & $\begin{array}{l}\text { Pulse group } \\
\text { duration }\end{array}$ & -0.236 & 0.473 & 0.248 \\
\hline SED & 0.221 & -0.650 & -0.168 & $\begin{array}{l}\text { Interpulse } \\
\text { group interval }\end{array}$ & 0.059 & 0.612 & 0.134 \\
\hline IND & 0.223 & 0.485 & -0.381 & $\begin{array}{l}\text { Pulses per } \\
\text { pulse group }\end{array}$ & -0.453 & 0.138 & 0.073 \\
\hline IOD & 0.196 & 0.016 & 0.326 & Pulse duration & -0.231 & -0.117 & 0.600 \\
\hline END & 0.255 & -0.093 & 0.012 & $\begin{array}{r}\text { Interpulse } \\
\text { duration }\end{array}$ & 0.328 & 0.396 & -0.342 \\
\hline RND & 0.234 & -0.328 & -0.530 & Pulse rate & -0.365 & -0.384 & -0.194 \\
\hline $\mathrm{ED}$ & 0.247 & -0.057 & -0.270 & $\begin{array}{l}\text { Dominant } \\
\text { frequency }\end{array}$ & 0.362 & -0.160 & -0.196 \\
\hline $\mathrm{HL}$ & 0.288 & 0.075 & -0.036 & & & & \\
\hline $\mathrm{FL}$ & 0.272 & 0.237 & 0.099 & & & & \\
\hline $\mathrm{TL}$ & 0.289 & 0.045 & 0.166 & & & & \\
\hline
\end{tabular}


Table 1 (continued).

(B) Individuals of the O. occidentalis-group

\begin{tabular}{|c|c|c|c|c|c|c|c|}
\hline \multirow{2}{*}{$\begin{array}{l}\text { Morphometric } \\
\text { variables with } \\
N=105 \\
\text { observations }\end{array}$} & PC1 & PC2 & PC3 & \multirow{2}{*}{$\begin{array}{l}\text { Call variables } \\
\text { with } N=75 \\
\text { observations }\end{array}$} & \multirow{2}{*}{$\begin{array}{l}\text { PC1 } \\
\text { Eigenwert: } \\
\text { 3.41 Variance } \\
\text { explained: } 37.9 \%\end{array}$} & \multirow{2}{*}{$\begin{array}{l}\text { PC2 } \\
\text { Eigenwert: } \\
1.99 \text { Variance } \\
\text { explained: } 22.1 \%\end{array}$} & \multirow{2}{*}{$\begin{array}{l}\text { PC3 } \\
\text { Eigenwert: } \\
1.62 \text { Variance } \\
\text { explained: } 18.0 \%\end{array}$} \\
\hline & $\begin{array}{l}\text { Eigenwert: } \\
10.53 \text { Variance } \\
\text { explained: } 70.2 \%\end{array}$ & $\begin{array}{l}\text { Eigenwert: } \\
0.79 \text { Variance } \\
\text { explained: } 5.3 \%\end{array}$ & $\begin{array}{l}\text { Eigenwert: } \\
0.69 \text { Variance } \\
\text { explained: } 4.6 \%\end{array}$ & & & & \\
\hline FOL & 0.284 & 0.052 & 0.121 & & & & \\
\hline F3L & 0.270 & 0.236 & -0.033 & & & & \\
\hline $\mathrm{T} 4 \mathrm{~L}$ & 0.270 & 0.135 & 0.094 & & & & \\
\hline
\end{tabular}

Note:

For details see text.

the individuals of each predefined group. Due to the partial sympatry among species of the O. occidentalis group we tested for clinal variation of PCs along latitudinal and altitudinal gradients by a multiple regression analysis (Procedure: backward selection at $F=4.0$ ).

\section{Allozyme data}

Liver samples were obtained from 147 individuals (Table S2). Samples were dissolved in one $\mathrm{ml}$ homogenate buffer (Tris-EDTA-NADP at $\mathrm{pH}$ 7.0) and stored at $-65{ }^{\circ} \mathrm{C}$ until use. Aliquots of 0.3-3 $\mu \mathrm{l}$ liver homogenate were applied to commercial cellulose acetate plates (PHERO-cel, $5.7 \times 14.0 \mathrm{~cm}$ ) and submitted to a continuous horizontal electrophoresis (Hebert \& Beaton, 1993). Buffer systems and duration of electrophoresis were 30-40 min at room temperature: (1) Tris-Glycine at $\mathrm{pH} 8.5$ and constant $200 \mathrm{~V}$;

(2) Citric acid aminopropyl morpholine at pH 7.0 and constant $130 \mathrm{~V}$. Following electrophoresis, each gel was stained using standard recipes (Murphy et al., 1996).

The allozyme pattern of liver tissue consisted of 10 enzyme systems controlled by a total of 14 putative loci: aspartate amino transferase (two loci, AAT, EC 2.6.1.1), carboxylesterase (1, EST, 3.1.1.1), glycerol-3-phosphate dehydrogenase (1, G3PD, 1.1.1.8), glucosephosphate isomerase (1, GPI, 5.3.1.9), isocitrate dehydrogenase (2, IDH, 1.1.1.42), lactate dehydrogenase (1, $\mathrm{LDH}, 1.1 .1 .27)$, malate dehydrogenase $(2, \mathrm{MDH}, 1.1 .1 .37)$, malic enzyme (1, ME, 1.1.1.40), 6-phosphogluconate dehydrogenase (1, 6PGD, 1.1.1.44), phosphoglucomutase (2, PGM, 2.7.5.1). Mitochondrial and cytoplasmatic loci were distinguished by prefixes $(\mathrm{m} / \mathrm{c})$, electromorphs (putative alleles) of each locus were designated alphabetically from cathode to anode. For reference, we used a sample of one O. americanus individual in each run.

Statistical analyses of data included the calculation of allele frequencies (Table S2) and Nei's unbiased genetic distances (Nei, 1972). Distances $>0.1$ were considered indicative for differentiation at species level (Highton, 1999; Scillitani \& Picariello, 2000). Calculation was performed using the program GENDIST of the Phylogeny Inference Package (PHYLIP, version 3.695) by Felsenstein (2008).

\section{Molecular phylogenetic analysis}

We compared the partial sequence of the mitochondrial 16S rRNA gene of the samples from the different localities in Argentina to assess the number of species present in 
the country and their phylogenetic relationships (Table S3). The $16 \mathrm{~S}$ barcoding gene is widely used, it amplifies with great success for most amphibians, there is a lot of available information already, and it is generally informative for tree-tips relationships, that is, among closely related species (Vences et al., 2005; Zhang et al., 2013). DNA was extracted using Qiagen DNeasy Blood and Tissue Kit (Qiagen, Hilden, Germany) following the manufacturer's protocol. Polymerase chain reaction (PCR) was used to amplify fragments of approximately $560 \mathrm{bp}$ of $16 \mathrm{~S}$ mitochondrial rRNA using the standard primers 16SAL (5'-CGCCTGTTTACTAAAAACAT-3'), and 16SBH (5'-CCGGTCTGAACTCAGAT CACGT-3'). Amplification followed the standard PCR conditions (Palumbi, 1996) with the following thermal cycle profile: $120 \mathrm{~s}$ at $94{ }^{\circ} \mathrm{C}$, followed by 33 cycles of $94{ }^{\circ} \mathrm{C}$ for $30 \mathrm{~s}, 49^{\circ} \mathrm{C}(12 \mathrm{~S}) / 53{ }^{\circ} \mathrm{C}(16 \mathrm{~S})$ for $30 \mathrm{~s}$, and extension at $65^{\circ} \mathrm{C}$ for $60 \mathrm{~s}$. All amplified PCR products were verified using electrophoresis on a $1.4 \%$ agarose gel stained with ethidium bromide. PCR products were purified using Highpure PCR Product Purification Kit (Roche Diagnostics, Risch-Rotkreuz, Switzerland). Sequencing of both strands was performed with the DYEnamic ET Terminator Cycle Sequencing Premixkit (GE Healthcare, Munich, Germany) for sequencing reactions run on a MegaBACE 1000 automated sequencer (GE Healthcare, Munich, Germany). Chromas lite 2.1.1 software (Technelysium Pty Ltd, South Brisbane, Australia; http://www.technelysium.com.au) was used to check and read the chromatograms of the sequences. The obtained sequences were compared with those in GenBank using a standard nucleotide-nucleotide BLAST search. Homologous sequences of Odontophynus as well as from species of the closely related genera Macrogenioglottus and Proceratophrys were downloaded from GenBank and incorporated in an alignment. Sequences of Pleurodema somuncurensis (Leptodactylidae), Rhinella marina (Bufonidae) and Ceratophrys cornuta (Ceratophrydae) were used as outgroups (Table S3) to represent related anuran families (Feng et al., 2017). The sequences were aligned using the MUSCLE algorithm (Edgar, 2004) implemented in MEGA 7 (Kumar, Stecher \& Tamura, 2016). The final alignment consisted of 552 bp. Pairwise distances were calculated in MEGA7. Distances $>1 \%$ were considered indicative for differentiation at species level (Sáez et al., 2014).

The general time-reversible model with proportion of invariable sites and gamma-distributed rate variation among sites $(G T R+I+G)$ was chosen as the best-fitting model of sequence evolution on the basis of the Akaike information criterion as implemented in jModelTest 2 (Darriba et al., 2012) and was applied in maximum likelihood (ML) and Bayesian inference (BI) analyses. ML was performed in MEGA 7 with heuristic searches with stepwise addition and TBR branch-swapping algorithm, generating 1,000 bootstrap replicates. BI was performed using MrBayes 3.2.5 (Ronquist et al., 2012). Two independent Metropolis-coupled Monte Carlo Markov Chain (Larget \& Simon, 1999) analyses were run for 10 Million generations, each with one hot and three cold chains and the temperature set at 0.2 . Trees were sampled every 5,000 generations. The first 500 samples of each run were discarded as burn-in, and the remaining trees from both runs were used to calculate a consensus tree and Bayesian posterior probabilities. 

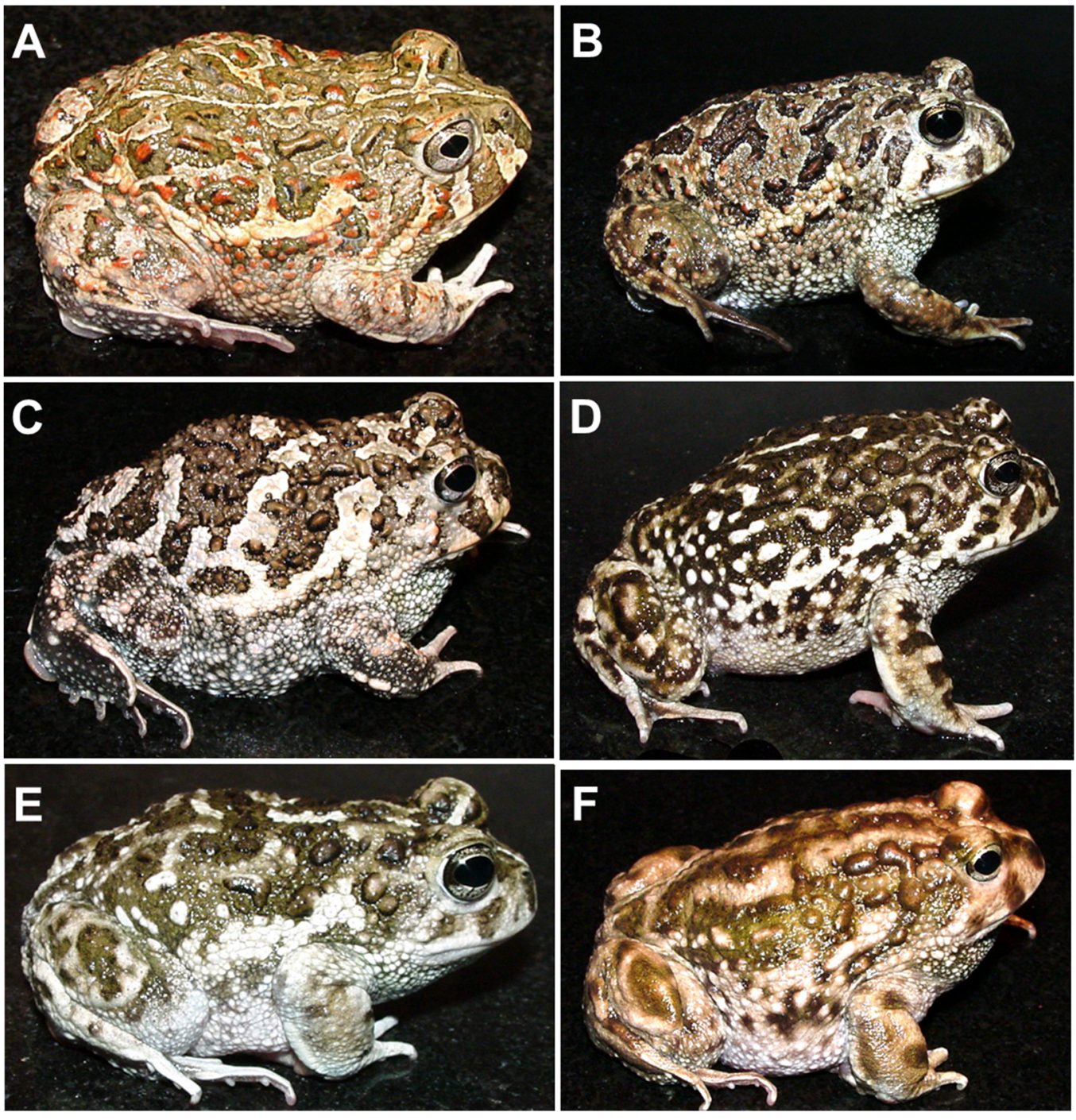

Figure 1 The nominal Odontophrynus taxa of Argentina. (A) O. americanus, (B) O. cordobae, (C) O. lavillai, (D) O. occidentalis, (E) O. achalensis, (F) O. barrioi. Dorsolateral view. Photographs by A. L. Martino.

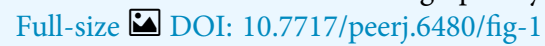

\section{RESULTS}

\section{Morphological variation}

All nominal taxa of Odontophrynus resemble each other considerably in coloration and external morphology reflecting their semi fossorial mode of living (Fig. 1).

Quantitative morphometric analyses demonstrated a significant morphological variation among some taxa. The three principal component representing the axes of morphospace explained $77.2 \%$ of total variance in the O. americanus group and $80.1 \%$ in the O. occidentalis group, respectively (Table 1). The morphospace of the O. americanus group was partitioned between $O$. lavillai on one side and the indistinguishable pair

O. americanus/O. cordobae on the other side (Fig. 2). The discriminant analysis confirmed a significant separation of $O$. lavillai with $85.7 \%$ of individuals correctly assigned to this 


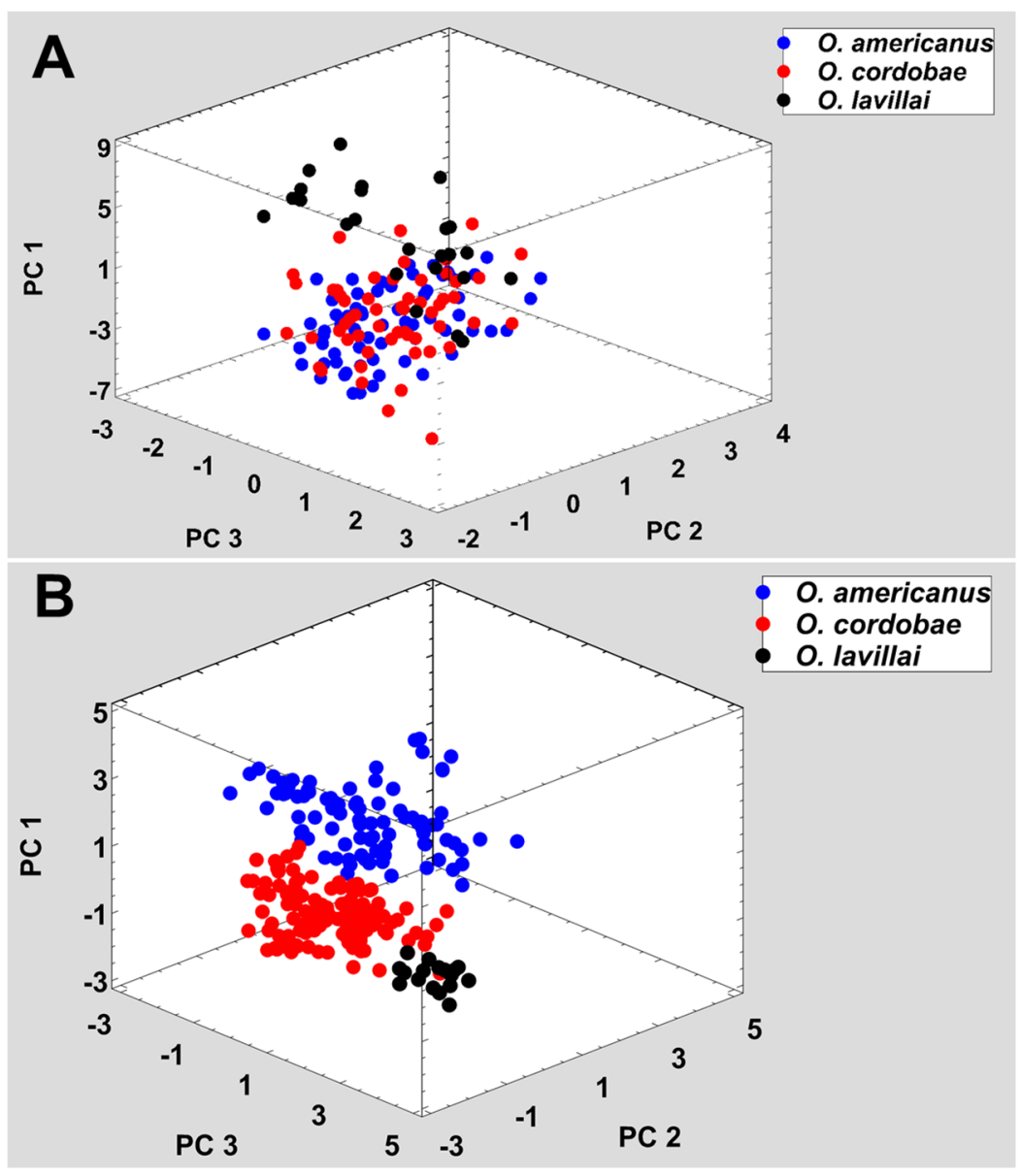

Figure 2 Phenotypic variation among the three nominal taxa included in the Odontophrynus americanus group. (A) Morphometric variation, (B) advertisement call variation. Each data point represents one individual.

Full-size 0 DOI: 10.7717 /peerj.6480/fig-2

species (Table 2). The taxa included in the O. occidentalis group showed a low morphometric differentiation with a wide overlap among O. occidentalis, O. achalensis and O. cf. achalensis (Fig. 3; Table 2). Classification success of discriminant function varied between $70 \%$ and $80 \%$ (Table 2). A significant proportion of morphometric variability among individuals assigned to the $O$. occidentalis group was caused by a clinal variation along altitudinal and latitudinal gradients. Size-related variation (PC1) was significantly correlated with altitude and latitude (Multiple regression model, $R^{2}=32.1 \%, F_{2,102}=24.03$, $P<0.00001$ ), that is, size of individuals increased with elevation and from south to north. PC2 (position of nares and eyes) was significantly correlated with latitude (Multiple regression model, $R^{2}=16.6 \%, F_{1,103}=20.52, P<0.00001$ ), PC3 (HL) with altitude (Multiple regression model, $R^{2}=10.0 \%, F_{1,103}=11.42, P=0.001$ ).

\section{Advertisement call variation}

The taxa of the O. americanus group emit simple and short pulsed advertisement calls, whereas those of the O. occidentalis group produce long and complex advertisement calls 
Table 2 Discriminant functions based on a subset of standardized morphometric variables (Procedure: backward selection).

\begin{tabular}{|c|c|c|c|c|c|c|c|}
\hline Discriminant function & Eigenwert & Percentage & $\begin{array}{l}\text { Canonical } \\
\text { correlation }\end{array}$ & $\begin{array}{l}\text { Wilks } \\
\text { lambda }\end{array}$ & Chi-squared & $\begin{array}{l}\text { Degrees } \\
\text { of freedom }\end{array}$ & $P$-value \\
\hline \multicolumn{8}{|l|}{ O. americanus-group } \\
\hline 1 & 1.91 & 95.7 & 0.810 & 0.316 & 168.7 & 8 & $<0.00001$ \\
\hline 2 & 0.09 & 4.3 & 0.283 & 0.920 & 12.2 & 3 & 0.0067 \\
\hline \multicolumn{8}{|l|}{ O. occidentalis-group } \\
\hline 1 & 3.81 & 81.6 & 0.890 & 0.100 & 228.1 & 20 & $<0.00001$ \\
\hline 2 & 0.44 & 9.5 & 0.554 & 0.480 & 72.6 & 12 & $<0.00001$ \\
\hline 3 & 0.35 & 7.5 & 0.511 & 0.693 & 36.3 & 6 & $<0.0001$ \\
\hline 4 & 0.07 & 1.4 & 0.249 & 0.938 & 6.3 & 2 & 0.0420 \\
\hline
\end{tabular}

\section{Standardized discriminant functions}

O. americanus-group O. occidentalis-group

\begin{tabular}{|c|c|c|c|c|c|c|}
\hline \multirow[b]{2}{*}{ Variables } & & & & & \\
\hline & 1 & 2 & 1 & 2 & 3 & 4 \\
\hline Maximum head width & & & 0.130 & 0.682 & -0.953 & -0.311 \\
\hline Snout-eye distance & & & -0.141 & 0.895 & 0.641 & 0.186 \\
\hline Tibia length & 0.692 & -1.11 & 0.454 & -1.028 & -0.441 & 0.427 \\
\hline Length of 3 rd finger & 0.344 & 0.436 & 0.434 & 0.274 & 0.604 & 0.590 \\
\hline Length of 4 th toe & & & 0.386 & -0.107 & 0.420 & -0.938 \\
\hline Eye-narinal distance & 0.370 & 0.333 & & & & \\
\hline Rostronarinal distance & -0.268 & 1.051 & & & & \\
\hline
\end{tabular}

\begin{tabular}{llll}
\hline & Predicted species & \\
\cline { 2 - 4 } Actual species & O. americanus & O. cordobae & O. lavillai \\
\hline O. americanus $(n=66)$ & $63.6 \%(n=42)$ & $36.4 \%(n=24)$ & - \\
O. cordobae $(n=57)$ & $38.6 \%(n=22)$ & $57.9 \%(n=33)$ & $3.5 \%(n=2)$ \\
O. lavillai $(n=28)$ & - & $14.3 \%(n=4)$ & $85.7 \%(n=24)$ \\
\hline
\end{tabular}

\begin{tabular}{|c|c|c|c|c|c|}
\hline \multirow[b]{2}{*}{ Actual species } & \multicolumn{5}{|c|}{ Predicted species } \\
\hline & O. occidentalis & O. achalensis & O. cf. achalensis & O. barrioi & O. cf. barrioi \\
\hline O. occidentalis $(n=29)$ & $75.9 \%(n=22)$ & $3.5 \%(n=1)$ & $10.3 \%(n=3)$ & $6.9 \%(n=2)$ & $3.5 \%(n=1)$ \\
\hline O. achalensis $(n=20)$ & - & $80.0 \%(n=16)$ & $20.0 \%(n=4)$ & - & - \\
\hline O. cf. achalensis $(n=15)$ & $6.6 \%(n=2)$ & $26.7 \%(n=4)$ & $77.3 \%(n=11)$ & - & - \\
\hline O. barrioi $(n=20)$ & - & - & $5.0 \%(n=1)$ & $70.0 \%(n=14)$ & $25.0 \%(n=5)$ \\
\hline O. cf. barrioi $(n=21)$ & $9.5 \%(n=2)$ & - & - & $19.1 \%(n=4)$ & $71.4 \%(n=15)$ \\
\hline
\end{tabular}

Note:

Analyses were run separately on the two phenetic Odontophrynus groups. The subset include the smallest combination of measured variables that maximizes classification success. For details see text.

consisting of a variable number of short pulse groups (Fig. 4). Quantitative analyses of the advertisement calls based on six temperature-adjusted variables in the

O. americanus group showed a significant variation among the three taxa. Three PCs explained $85.3 \%$ of total variance represented the axes of sound space (Table 1). The sound space was partitioned into three discrete groups representing O. americanus, O. cordobae and O. lavillai individuals, respectively (Fig. 2). The discriminant analysis assigned all but five calls correctly to the corresponding taxon (Table 3 ). 


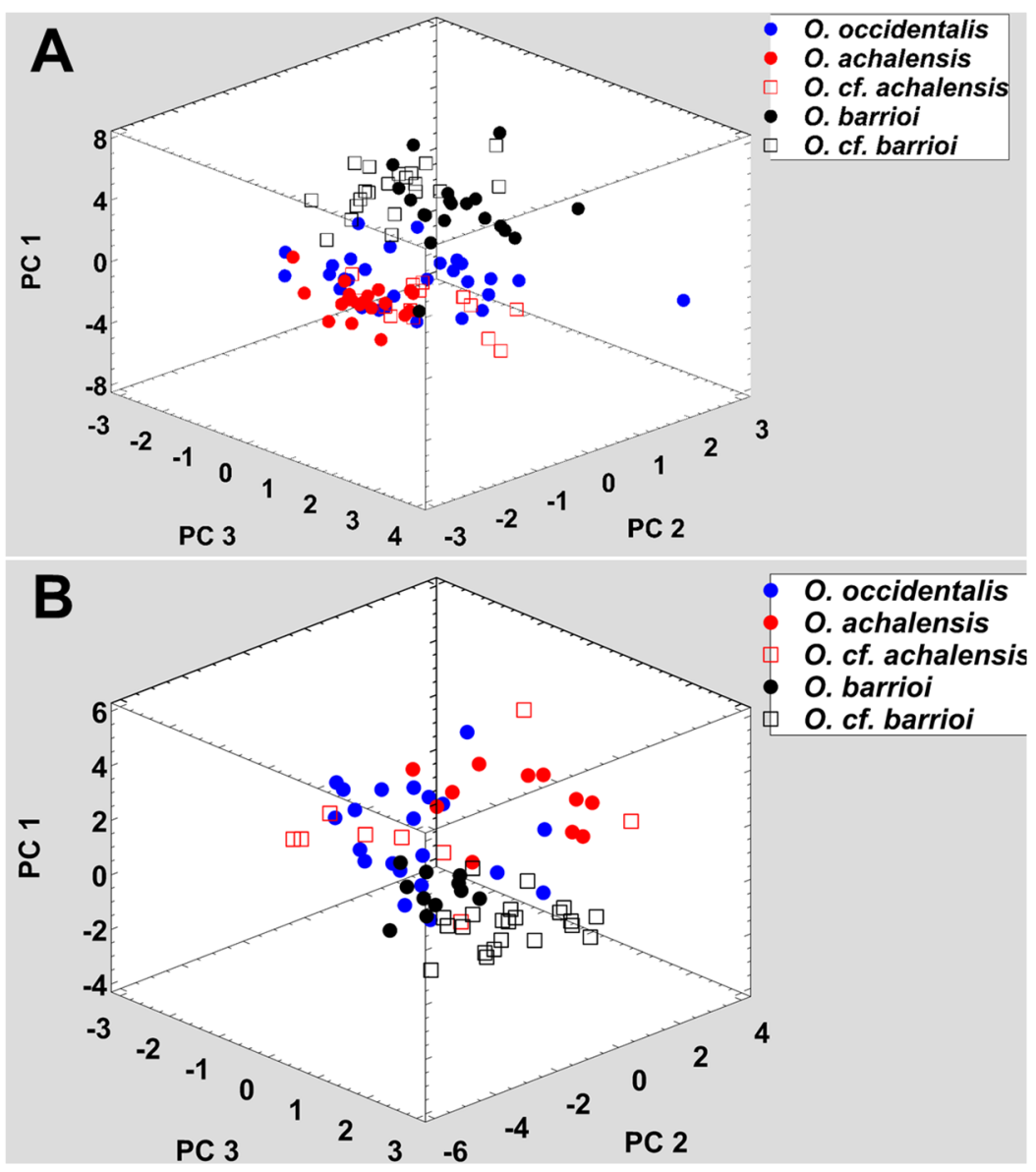

Figure 3 Phenotypic variation among the five nominal taxa included in the Odontophrynus occidentalis group. (A) Morphometric variation, (B) advertisement call variation. Each data point represents one individual. Full-size 0 DOI: 10.7717 /peerj.6480/fig-3

Analogous to morphometric variation, sound space partitioning was low among the taxa of the O. occidentalis group, with O. occidentalis, O. achalensis and O. cf. achalensis being indistinguishable among each other (Fig. 3; Table 3). The sound space occupied by $O$. barrioi and $O$. cf. barrioi differed from the continuum formed by the other taxa, but showed a slight overlap between each other. Still, the correct classification rates for O. barrioi and O. cf. barrioi were $100 \%$ and $95.4 \%$, respectively (Table 3).

Temperature-adjusted advertisement call variation was also influenced by geographical clines. PC1 (size-related dominant frequency) and PC2 (call duration) were significantly correlated with latitude (Multiple regression models: $R^{2}=9.8 \%, F_{1,74}=7.94$, $P=0.0062$, and $R^{2}=14.1 \%, F_{1,74}=11.97, P=0.0009$, respectively), and PC3 (pulse group duration) with altitude $\left(R^{2}=9.1 \%, F_{1,74}=7.31, P=0.0085\right)$.

\section{Genetic distances: allozymes and barcoding}

A total of 14 putative loci were scored in the nominal taxa (Table S2). Two loci (mAAT, mMDH) were monomorphic in all taxa. The overall degree of allele fixation was high and varied between five loci in O. americanus and 11 in O. lavillai. Five taxa possessed 


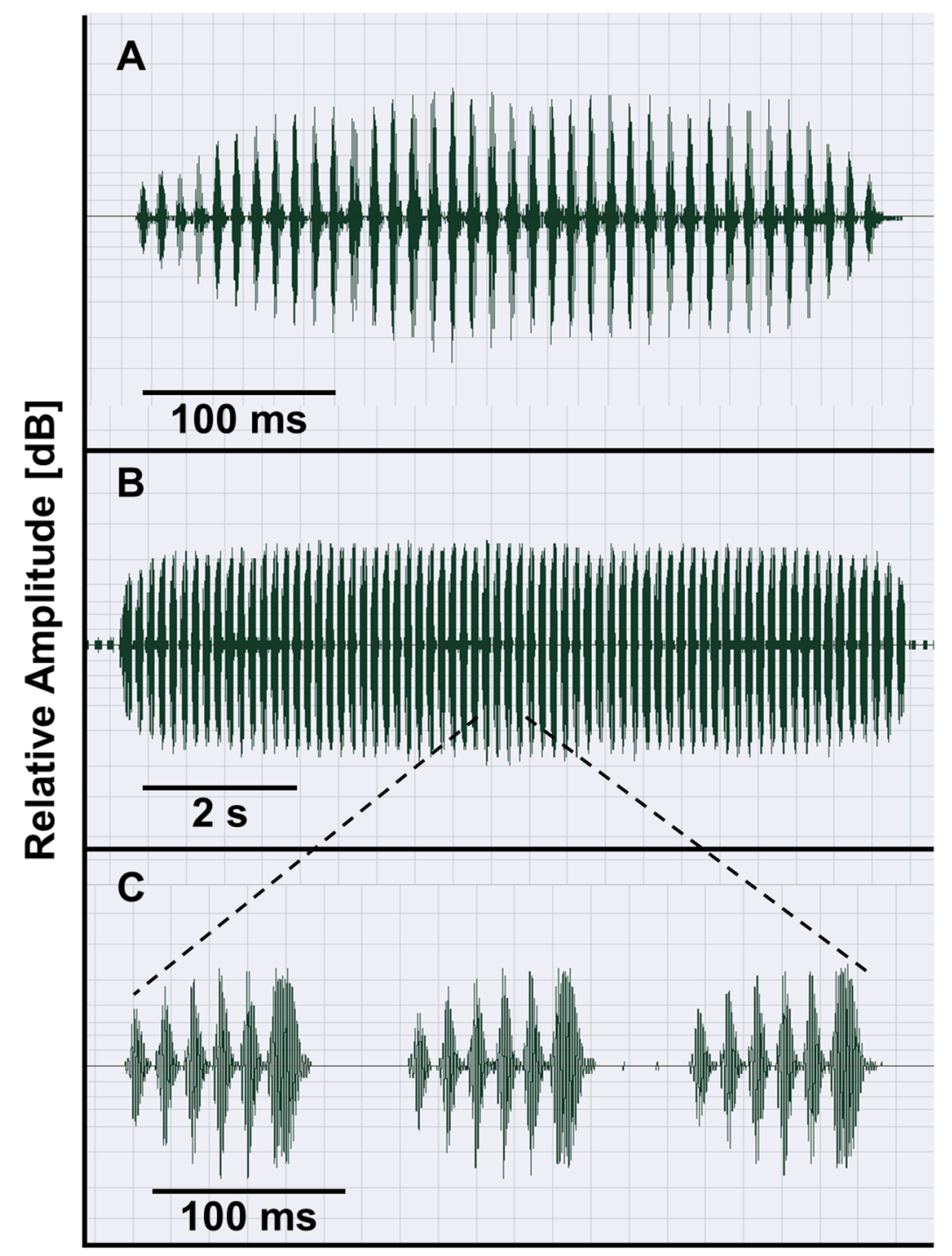

Figure 4 Advertisement calls of $O$. americanus (A) and O. occidentalis $(\mathrm{B}, \mathrm{C})$ as representatives of the two phenetic groups of Odontophrynus in Argentina. Oscillograms show calls recorded at $19.5^{\circ} \mathrm{C}$ water temperature (A) and at $17.5^{\circ} \mathrm{C}$ water temperature (B). Three pulse groups of the complex advertisement call of $O$. occidentalis (B) are presented in (C). Full-size

one private allele each: O. americanus cIDH a, O. lavillai cAAT a, O. achalensis LDH d, $O$. cf. achalensis GPI d and O. barrioi cMDH a. The pairwise Nei distances among the taxa were clearly below species level in four taxon pairs (Table 4): 0.0220 in O. americanus/O. cordobae, 0.0232 in O. achalensis/O. occidentalis, 0.0292 in O. cf. achalensis/O. occidentalis, and 0.0351 in O. achalensis/O. cf. achalensis.

The 25 samples from eight nominal Odontophrynus species differed from each other in the $16 \mathrm{~S}$ sequences by uncorrected pairwise distances of $0.0-7.3 \%$ (Table 5 ). The divergence between samples of $O$. achalensis, O. barrioi, O. cf. barrioi and O. occidentalis were minimal $(0.0-0.9 \%)$ and we regard them as belonging to a single species. The distances among the three nominal species O. americanus, O. cordobae and O. lavillai collected in 
Table 3 Discriminant functions based on based on a subset of standardized advertisement call variables (Procedure: backward selection).

\begin{tabular}{|c|c|c|c|c|c|c|c|}
\hline Discriminant function & Eigenwert & Percentage & Canonical correlation & Wilks lambda & Chi-squared & Degrees of freedom & $P$-value \\
\hline \multicolumn{8}{|l|}{ O. americanus-group } \\
\hline 1 & 6.67 & 84.1 & 0.933 & 0.058 & 633.5 & 10 & $<0.00001$ \\
\hline 2 & 1.26 & 25.9 & 0.747 & 0.443 & 181.1 & 4 & $<0.00001$ \\
\hline \multicolumn{8}{|l|}{ O. occidentalis-group } \\
\hline 1 & 12.25 & 90.3 & 0.962 & 0.028 & 245.5 & 24 & $<0.00001$ \\
\hline 2 & 0.86 & 6.3 & 0.679 & 0.368 & 68.5 & 15 & $<0.00001$ \\
\hline 3 & 0.44 & 3.2 & 0.552 & 0.683 & 26.2 & 8 & 0.0010 \\
\hline \multirow[t]{3}{*}{4} & 0.02 & 0.2 & 0.137 & 0.981 & 1.30 & 3 & 0.7296 \\
\hline & & \multicolumn{6}{|c|}{ Standardized discriminant functions } \\
\hline & & O. americanu & group & O. occidenta & $s$-group & & \\
\hline \multicolumn{2}{|l|}{ Variables } & 1 & 2 & 1 & 2 & 3 & 4 \\
\hline \multicolumn{2}{|l|}{ Call duration } & 0.877 & -0.429 & & & & \\
\hline \multicolumn{4}{|l|}{ Pulse group duration } & -0.636 & -2.144 & -0.107 & -1.092 \\
\hline \multicolumn{4}{|l|}{ Interpulse group intervall } & -0.888 & -0.187 & -0.200 & 0.562 \\
\hline \multicolumn{2}{|l|}{ Pulses per pulse group } & -0.423 & 0.202 & -0.503 & 1.450 & -0.419 & 0.442 \\
\hline \multicolumn{2}{|l|}{ Pulse duration } & 0.275 & -0.406 & 1.205 & 0.744 & 0.353 & 1.315 \\
\hline \multicolumn{2}{|l|}{ Interpulse group intervall } & & & 1.969 & 1.358 & 1.089 & 0.745 \\
\hline \multicolumn{2}{|l|}{ Pulse rate } & -0.713 & -0.465 & & & & \\
\hline \multicolumn{2}{|l|}{ Dominant frequency } & 0.339 & 0.672 & 0.797 & -0.157 & -0.579 & 0.013 \\
\hline
\end{tabular}

\begin{tabular}{llll}
\hline & Predicted species & \\
\cline { 2 - 4 } Actual species & O. americanus & O. cordobae & O. lavillai \\
\hline O. americanus $(n=91)$ & $98.9 \%(n=90)$ & - & $1.1 \%(n=1)$ \\
O. cordobae $(n=119)$ & $0.8 \%(n=1)$ & $96.6 \%(n=115)$ & $2.5 \%(n=3)$ \\
O. lavillai $(n=17)$ & - & - & $100 \%(n=17)$ \\
\hline
\end{tabular}

\begin{tabular}{|c|c|c|c|c|c|}
\hline \multirow[b]{2}{*}{ Actual species } & \multicolumn{5}{|c|}{ Predicted species } \\
\hline & O. occidentalis & O. achalensis & O. cf. achalensis & O. barrioi & O. cf. barrioi \\
\hline O. occidentalis $(n=21)$ & $52.4 \%(n=11)$ & $23.8 \%(n=5)$ & $23.8 \%(n=5)$ & - & - \\
\hline O. achalensis $(n=11)$ & - & $90.9 \%(n=10)$ & $9.9 \%(n=1)$ & - & - \\
\hline O. cf. achalensis $(n=10)$ & $40.0 \%(n=4)$ & $20.0 \%(n=2)$ & $40.0 \%(n=4)$ & - & - \\
\hline O. barrioi $(n=11)$ & - & - & - & $100 \%(n=11)$ & - \\
\hline O. cf. barrioi $(n=22)$ & - & - & - & $4.6 \%(n=1)$ & $95.4 \%(n=21)$ \\
\hline
\end{tabular}

Note:

Analyses were run separately on the two phenetic Odontophrynus groups. The subset include the smallest combination of measured variables that maximizes classification success. For details see text.

Argentina were at species level (1.8-2.7\%). Interestingly, the specimens referred to as O. americanus from Brazil (Amaro, Pavan \& Rodrigues, 2009; Lyra, Haddad \& De Azeredo-Espin, 2017) resolved into three groups differing at species level among each other (2.4-4.0\%). The topotypic O. americanus from Argentina was conspecific with the Rio Grande specimen (southern Brazil; $P$-distance $=0.4 \%$ ). Genetic differentiation among the specimens collected in Argentina delimits four Odontophrynus species (Fig. 5). 
Table 4 Nei's genetic distances among six nominal Odontophrynus taxa and and two achalensis- and barrioi-like populations.

\begin{tabular}{|c|c|c|c|c|c|c|c|}
\hline Taxon & O. cordobae & O. lavillai & O. occidentalis & O. achalensis & O. cf. achalensis & O. barrioi & O. cf. barrioi \\
\hline O. americanus & 0.0220 & 0.1853 & 0.1821 & 0.1942 & 0.2452 & 0.4196 & 0.5471 \\
\hline O. cordobae & & 0.2224 & 0.2084 & 0.2146 & 0.2707 & 0.4160 & 0.5943 \\
\hline O. lavillai & & & 0.2781 & 0.4126 & 0.4982 & 0.6705 & 0.5608 \\
\hline O. occidentalis & & & & 0.0232 & 0.0292 & 0.1846 & 0.2604 \\
\hline O. achalensis & & & & & 0.0351 & 0.1660 & 0.3422 \\
\hline O. cf. achalensis & & & & & & 0.1772 & 0.3406 \\
\hline O. barrioi & & & & & & & 0.2186 \\
\hline
\end{tabular}

Note:

Distances were calculated from the allele frequencies listed in S2.

\section{Phylogenetic relationships among the Odontophrynidae}

The topologies derived from the two phylogenetic analysis methods were largely congruent. We show the BI phylogeny with bootstrap values from ML and posterior probabilities from BI (Fig. 5). In agreement with earlier phylogenies (Amaro, Pavan \& Rodrigues, 2009; Pyron \& Wiens, 2011; Dias et al., 2013; Feng et al., 2017) our data support the monophyly of the three genera within Odontophrynidae and the sister group relationship between Macrogenioglottus and all Odontophrynus taxa. The Proceratophrys clade resolved as the sister group to the clade formed by the other two genera. The samples of Odontophrynus resolved into two major clades with strong node support. The first one contained the samples of O. occidentalis as well as those of O. achalensis and O. barrioi. The relationships within this clade remained largely unresolved and the three nominal taxa did not separate into distinct phylogenetic lineages. The second clade contained the remaining species divided into two subclades, one consisting of $O$. carvalhoi and O. cultripes, the other one containing O. americanus, O. cordobae and O. lavillai. The samples of $O$. americanus did not form a monophyletic clade since the topotypic Argentinian sample and the specimen from southern Brazil were more closely related to O. cordobae and O. lavillai than to the other Brazilian samples referred to as O. americanus.

\section{Synonymy and updated diagnosis of 0 . occidentalis (Berg, 1896)}

Since we did not detect significant genetic differentiation among O. achalensis, O. barrioi and O. occidentalis, we consider these three nominal taxa as a single species. Applying the Principle of Priority of the International Code of Zoological Nomenclature (International Commission on Zoological Nomenclature, ICZN, 1999), the oldest available name is O. occidentalis.

Synonymy. Besides the names C. occidentalis Berg, 1896 and O. occidentalis Müller, 1934, we place the names O. barrioi Cei, Ruiz, and Beçak, 1982, and O. achalensis Di Tada et al., 1984 into the synonymy of O. occidentalis (Berg, 1896).

Holotype. Male (MACN 380), housed in the Museo Argentino de Ciencias Naturales "Bernardino Rivadavia", Buenos Aires, Argentina (Rosset et al., 2007). Type locality: “Arroyo Agrio (Neuquén)”, Argentina. 


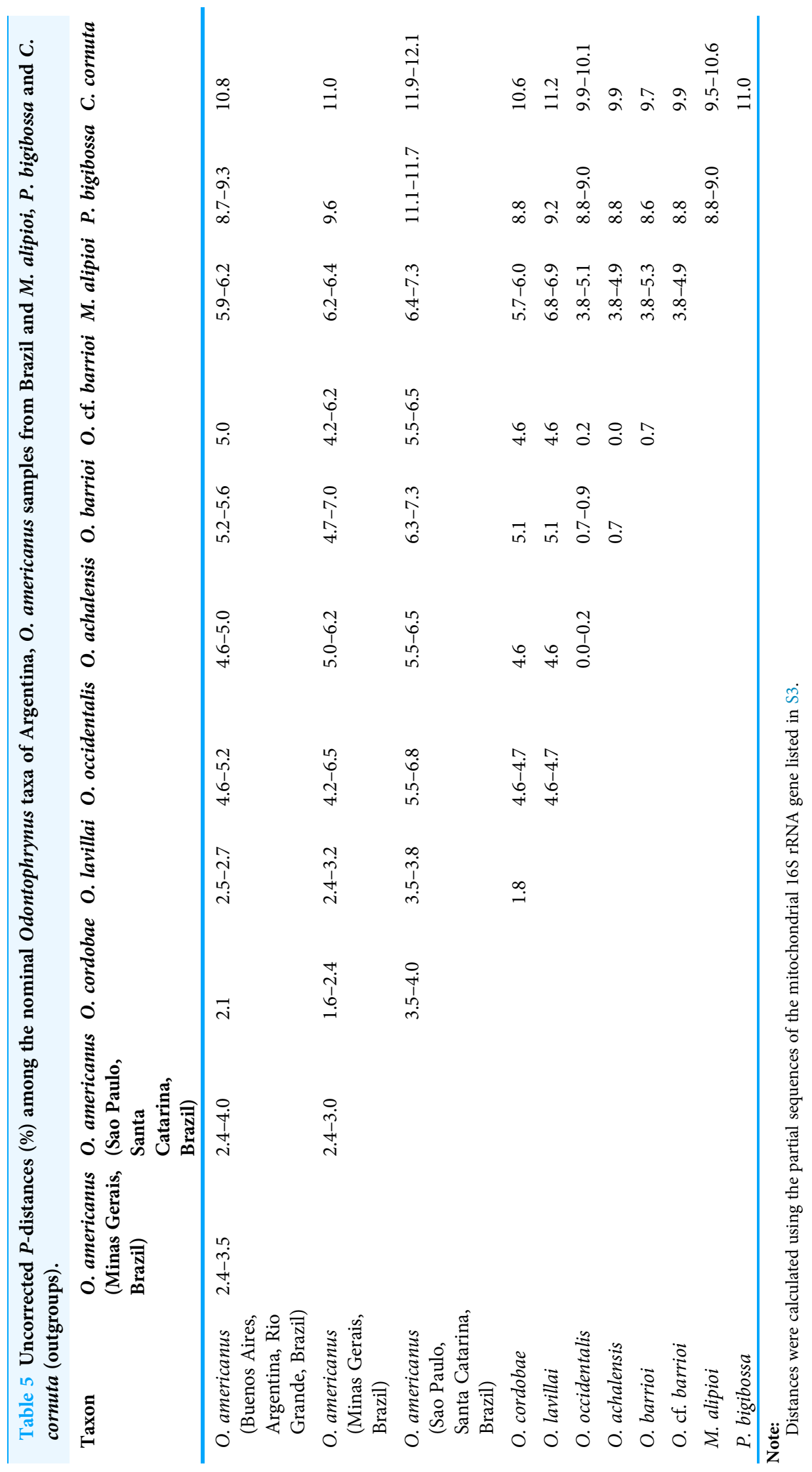




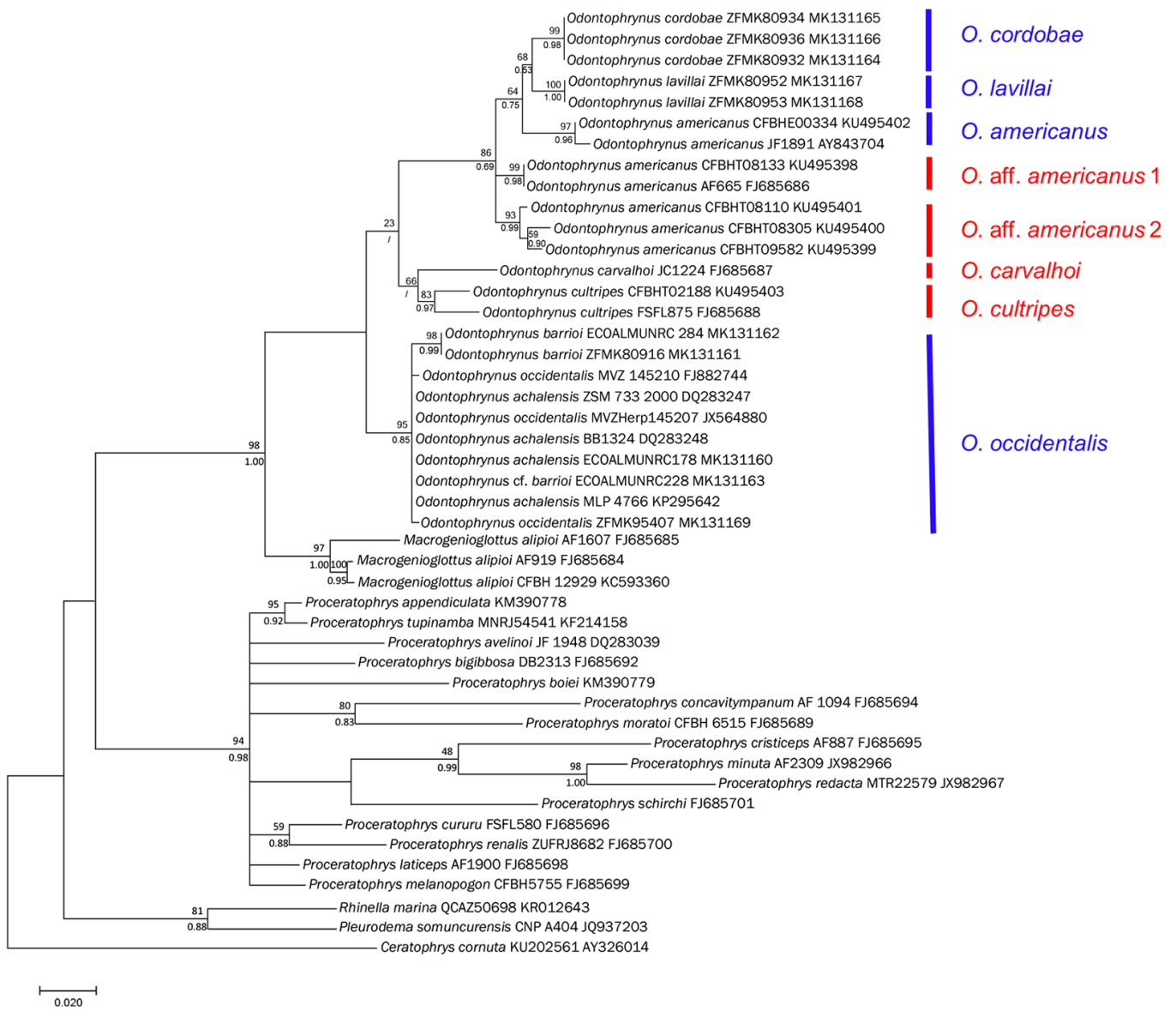

Figure 5 Bayesian phylogram on Odontophrynidae inferred from mitochondrial nucleotide sequence data of 16S rRNA. Numbers above branches are non-parametric bootstrap support values from MP and ML, respectively, numbers below branches are Bayesian posterior probabilities. In two cases with low bootstrap support, the nods were not supported by Bayesian approach. Blue bars indicate the four genetically delimited species occurring in Argentina, red bar the species occurring in Brazil. Please note that $O$. aff. americanus 1 and 2 are undescribed taxa which differ from the topotypical O. americanus from Argentina and southern Brazil. Full-size $\boldsymbol{i}$ DOI: $10.7717 /$ peerj.6480/fig-5

Molecular diagnosis. The partial mitochondrial 16S RNA gene sequences of 10 specimens collected throughout the geographical range (Table S3) are unique within the genus Odontophrynus, show a low within-taxon range of variation $(0.0-0.9 \%$ uncorrected $P$-distances) and differ significantly from the corresponding sequences of $O$. americanus, O. cordobae and O. lavillai (4.6-5.2\% uncorrected P-distances; Table 5) originating from Argentina.

Karyological diagnosis. The karyotype of $O$. occidentalis is diploid with $2 n=22$ chromosomes as in O. cordobae and in O. lavillai, distinguishing these species from the tetraploid O. americanus (Barrio \& Pistol de Rubel, 1972; Cei, Ruiz \& Beçak, 1982; Ruiz, Cei \& Beçak, 1982; Salas, Steinlein \& Schmid, 2000; Rosset et al., 2006; Salas \& Martino, 2007). Secondary constrictions are present on pair 4 in some O. americanus, all O. cordobae and O. lavillai and on pair 8 in O. cordobae and on pair 11 in O. americanus 
and O. occidentalis (Barrio \& Pistol de Rubel, 1972; Rosset et al., 2006; Salas \& Martino, 2007). The intercalary C-band on chromosome 9 is characteristic for all studied O. occidentalis populations, that is, present in the achalensis, barrioi and occidentalis ecotypes, but absent in the other Odontophrynus spp. (Ruiz, Cei \& Beçak, 1982). C-banding patterns shows some variability among populations, with additional bands on chromosome 1 (barrioi), 2 and 3 (barrioi, occidentalis), and 4 (achalensis) (Ruiz, Cei \& Beçak, 1982; Salas, Steinlein \& Schmid, 2000). Odontophrynus occidentalis is diagnosed karyologically by the combination of $2 n=22$ chromosomes, secondary constrictions on chromosome pair 11 and an intercalary C-band on chromosome 9.

Morphological diagnosis of adults. Odontophrynus occidentalis are short-legged and stout as all described Odontophrynus toads. Enlarged to rounded paratoid glands are present. Sexual size dimorphism absent. Individuals of lowland populations on average smaller than those of highland populations. In life, the dorsal color is brownish with brown spots and faint lateral and dorsal yellowish longitudinal bands, expression of light vertebral stripe variable from absent to short at the head or urostyle (Fig. 1).

Ventral background color is whitish with scattered white granuli.

Further qualitative features are in wide agreement with the original descriptions in Berg (1896), Cei, Ruiz \& Beçak (1982), Di Tada et al. (1984), Cei (1985) and Rosset et al. (2007). (1) Nostrils nearer to the snout than to the eyes, in lateral profile; (2) lateral fringes poorly or not developed on fingers; (3) metatarsal tubercle shovel-like, moderately developed; (4) short fore and hind limbs; (5) ED 1.7 times greater than eye-nostril distance; (6) interorbital distance longer than the upper eyelid width; (7) tibia slightly shorter than femur; (8) HL approximately one third of the SVL; (9) keratinous spines on the dorsum present mainly in highland populations. Among- and within-population variation exist in shape, size and number of the dorsal glands and in the presence and number of keratinous spines on the dorsum (Di Tada et al., 1984; Rosset et al., 2007).

Crespo \& Cei (1983) proposed several morphometric ratios (tibiofibula length/fourth toe length, sacrum width/total length, sacrum width/vertebral column length, skull length/total length) to distinguish barrioi from occidentalis ecotypes. Rosset et al. (2007) rejected this proposal. Quantitative features (median, range in [mm]) of 92 males and 13 females are calculated irrespective of altitude and latitude at collection locality. (1) SVL: 54.1 (36.3-71.2, males) vs. 51.0 (42.0-71.2, females); (2) HW: 24.5 (15.4-29.6) vs. 24.4 (19.2-31.4); (3) HL: 18.3 (11.1-24.9) vs. 17.8 (13.1-23.4); (4) SED: 8.6 (5.1-10.9) vs. 8.1 (5.6-10.2); (5) IND: 4.0 (3.1-5.5) vs. 3.8 (2.7-5.6); (6) IOD: 3.6 (2.6-4.7) vs. 3.9 (2.8-5.1); (7) END: 4.5 (3.1-6.5) vs. 4.4 (2.8-6.1); (8) RND: 5.4 (3.3-6.7) vs. 5.0 (3.0-6.3); (9) ED: 7.5 (5.6-10.4) vs. 7.4 (5.5-9.8); (10) HL: 24.4 (15.9-33.4) vs. 24.4 (17.5-34.5); (11) F3L: 7.6 (5.9-11.6) vs. 8.1 (5.9-11.5); (12) FL: 22.3 (15.5-32.0) vs. 20.4 (15.1-29.8); (13) TL: 20.0 (13.4-26.8) vs. 19.8 (14.5-25.4); (14) FOL: 33.0 (22.4-45.1) vs. 31.5 (24.1-46.6); (15) T4L: 11.1 (6.9-16.7) vs. 10.6 (7.9-18.4).

Morphological diagnosis of tadpoles. In the exotrophic, lentic and benthic Odontophrynus spp. tadpoles, the body is ovoid in dorsal and ventral views and slightly 
depressed in lateral view, the snout is circular in dorsal and ventral views with an anteroventral oral disc, the eyes and nostrils placed dorsally, and the spiracle sinistral, short, and with an opening posterodorsally directed (Do Nascimento et al., 2013). Odontophrynus occidentalis differs from the other species by being considerably larger at stages 36-38 (average: $71.7 \mathrm{~mm}$; maximum: $75 \mathrm{~mm}$ (Cei, 1987). Do Nascimento et al. (2013) and González et al. (2014) state that external tadpole morphology is very similar in the achalensis, barrioi and occidentalis ecotypes, unlike Cei \& Crespo (1982). Shared characters apart from the general Odontophrynus spp. features are a tail, that is, larger than half of the total length with robust musculature and 2(2)/3(1) as labial tooth row formula. Among the distinguishing characters mentioned by Cei et al. (1982), Cei \& Crespo (1982) and Cei (1987) for the barrioi ecotype, only the diverging form of the tip of tail (rounded contrary to acuminate in occidentalis and achalensis) has been confirmed by González et al. (2014). The significance of this difference remains unclear because phenotypic plasticity of tail morphology in response to syntopic predators is well-documented (Van Buskirk, 2009).

Bioacoustic diagnosis. Odontophrynus occidentalis is unique among all currently known Odontophrynus species by giving series of complex advertisement calls consisting of a variable number of pulse groups (Figs. 4B and 4C). Rosset et al. (2007) state that advertisement call features in the ecotypes achalensis, barrioi and occidentalis are very similar. The bioacoustic distinction of achalensis from occidentalis (Salas \& Di Tada, 1994) and of barrioi from the other ecotypes (Rosset et al., 2007) is based mainly on differences in the dominant frequency (related to body size), in call duration (sensitive to environmental temperature), and in intercall interval (sensitive to behavioral interactions such as chorusing; Schneider \& Sinsch, 2007). In fact, temperature-adjusted dominant frequency Standardized Dominant Frequency (SDF) was significantly correlated with SVL of the caller demonstrating that ecotype distinction reflects mainly size variation among populations (Linear regression model: SDF $=2.405-0.065^{*} \mathrm{SVL}$, $R^{2}=0.623 ; F_{1,74}=120.6, P<0.0001$; Fig. S1). SVL- and temperature-adjusted call duration did not differ significantly among the ecotypes (ANOVA, $F_{4,74}=2.14, P=0.084$ ).

The following features (median, range, $n=229$ ) of O. occidentalis advertisement calls are calculated irrespective of the size of the calling individual and of ambient temperature, altitude and latitude at recording locality. (1) Call duration 2,619 ms (767-64,303 ms); (2) pulse groups per call 18 (5-348); (3) pulse group duration $98 \mathrm{~ms}$ (60-171 ms); (4) pulses per pulse group 7 (5-11); (5) interpulse group interval $57 \mathrm{~ms}$ (38-97 ms); (6) pulse duration eight ms (4-13 ms); (7) interpulse interval six ms (2-16 ms); (8) pulse rate: 48.3 pulses/s (24.9-65.3 pulses/s); and (9) dominant frequency $754 \mathrm{~Hz}(553-955 \mathrm{~Hz})$. Features of the encounter call are given in Rosset et al. (2007).

Geographic and habitat range. Populations are present in a latitudinal range from $41^{\circ} \mathrm{S}$ in the Rio Negro Province to $27.5^{\circ} \mathrm{S}$ in the north of the Catamarca Province (Ruiz, Cei \& Beçak, 1982; Rosset et al., 2007). The corresponding altitudinal range is from $690 \mathrm{~m}$ above sea level to 1,854 m in the Sierra Pie de Palo, 1,965 m in the Sierra de San Luis, 
2,149 $\mathrm{m}$ in the Sierra de Achala, and 2,200 $\mathrm{m}$ in the Sierra de Famatina (Table S1). Terrestrial habitats include pastureland, montane grassland, shrubs, forests and rock outcrops. Aquatic habitats used for reproduction and larval development are exclusively creeks and slowly running rock pool sections of permanent streams.

\section{DISCUSSION}

Lines of evidence obtained from phenotypic and genotypic character complexes in Odontophrynus toads exemplify the common dilemma of taxonomy-which level of character differentiation requires taxonomic consequences? Our case study demonstrates that phenotypic plasticity may result in an overestimation of species number (O. occidentalis group), whereas molecular data may reveal unexpected cryptic diversity in morphologically uniform populations (referred to as O. americanus). The following discussion of the three hypotheses basic to our investigation will present a revised view on the actual Odontophrynus species richness and propose a model of the phylogenetic relationships within the genus Odontophrynus.

\section{Hypothesis 1: Phenotypic plasticity within and among Odontophrynus taxa is associated with corresponding genetic differentiation}

Applying the consensus protocol for integrative taxonomy (Padial et al., 2010) we evaluate the support for the genetically delimited species O. americanus, O. cordobae, O. lavillai and O. occidentalis by the among-taxon variation of allozyme, morphology and bioacoustic character complexes. Congruence of genetic and phenotypic differentiation clearly delimits O. lavillai from the congeneric taxa in Argentina. Independent support for its distinction from the only sympatric Odontophrynus species stems from karyological features, that is, O. lavillai is diploid whereas topotypic O. americanus is tetraploid (Barrio \& Pistol de Rubel, 1972; Cei, 1985; Rosset \& Baldo, 2014). Natural hybrids between these species have not been detected.

The significant differentiation of 16S RNA gene sequence distinguishes between the tetraploid O. americanus and the diploid O. cordobae as does the advertisement call structure (Martino \& Sinsch, 2002; this study). Congruent allozyme and morphometric differentiation seem to be absent (Barrio \& Pistol de Rubel, 1972; this study). However, adjusting size by age reveals that the two species differ significantly in their ontogenetic growth trajectories (Martino \& Sinsch, 2002) supporting the molecular distinction. Premating isolation mechanisms allow the two species to maintain reproductive isolation in the narrow zone of sympatry, as indicated by a very low incidence of triploid hybrids at only two localities (Grenat et al., 2018). Thus, cumulating available evidence on character differentiation (except for the allozyme pattern) supports the species status of these two taxa.

To our surprise, the 16S RNA gene sequence of a topotypical tetraploid O. americanus from the Buenos Aires province, Argentina and that of five specimens of unknown ploidy referred to as O. americanus from different localities in Brazil (Amaro, Pavan \& Rodrigues, 2009; Lyra, Haddad \& De Azeredo-Espin, 2017) differed so profoundly that we consider them as a complex of three distinct species. One sample from Rio Grande, 
Brazil proved to be very similar to the topotypical tetraploid O. americanus indicating that this species extends over Uruguay to southern Brazil. A second group of two specimens originating from southern Minas Gerais is termed here as $O$. aff. americanus 1 and a distinct species from topotypical tetraploid O. americanus. Its distinction from or similarity with the diploid O. juquinha from northern Minas Gerais remains to be studied in the future. Finally, a third group of three specimens from Sao Paulo and Santa Catarina provinces, termed here as $O$. aff. americanus 2, is a distinct species from Minas Gerais taxon and true $O$. americanus. One of these specimens originated from Irai which is about $100 \mathrm{~km}$ distant from the "O. americanus"-populations reported from the province Misiones, Argentina (Rosset et al., 2006). It seems reasonable to assume that the geographical range of $O$. aff. americanus 2 extends to Argentina in the west, but further studies are needed to resolve the relationship to the Misiones populations.

In contrast, we did not detect any significant genetic differentiation among the specimens belonging to different nominal taxa of the $O$. occidentalis group despite a considerable phenotypic plasticity among and within populations. Broadly overlapping variation in all character complexes surveyed demonstrates that $O$. achalensis from the Sierra de Cordoba and associated populations from the Sierra de San Luis are phenotypically and genetically indistinguishable from O. occidentalis. Sympatry of the two forms in the Sierra de Cordoba suggests ongoing gene flux between lowland and highland phenotypes. The taxonomic conclusion is straightforward-O. achalensis does not deserve species status; it is simply the highland ecotype of the eastern and central part of the O. occidentalis range. Applying the Principle of Priority of the International Code of Zoological Nomenclature (International Commission on Zoological Nomenclature, ICZN, 1999), we consider O. achalensis a junior synonym of O. occidentalis.

The case of $O$. barrioi is more complicated because the absence of significant genetic differentiation from $O$. occidentalis contrasts with considerable morphometric, bioacoustic and allozyme differentiation. The $O$. barrioi populations vary morphometrically only by their greater size whereas shape variation is the same as in the O. occidentalis/ O. achalensis continuum. Within-species altitudinal and latitudinal size variation is well known in anurans (Sinsch, Pelster \& Ludwig, 2015), and SVL differences alone appear to be poor indicators of species distinction (Rakotoarison et al., 2012; Rojas et al., 2016). Advertisement call variation is mainly based on differences in dominant frequency, again an indicator of size of the calling individual (Fig. S1) and thus, of low taxonomic significance. The features of qualitative external morphology proposed by Rosset et al. (2007) to diagnose O. achalensis, O. barrioi and O. occidentalis represent the extremes of a continuum between lowland and highland ecotypes, and between eastern and northern variants of the same species. For the same reason González et al. (2014) failed to detect significant morphological differences among the tadpoles within the O. occidentalis group refuting the claim of Cei \& Crespo (1982). Moreover, defensive behavior of adults is also indistinguishable (Borteiro et al., 2018). Thus, the phenotypic peculiarities of $O$. barrioi seem responses to local environmental conditions rather than indicating taxonomically relevant information. Applying the Principle of Priority of the International Code of Zoological Nomenclature (International Commission on 


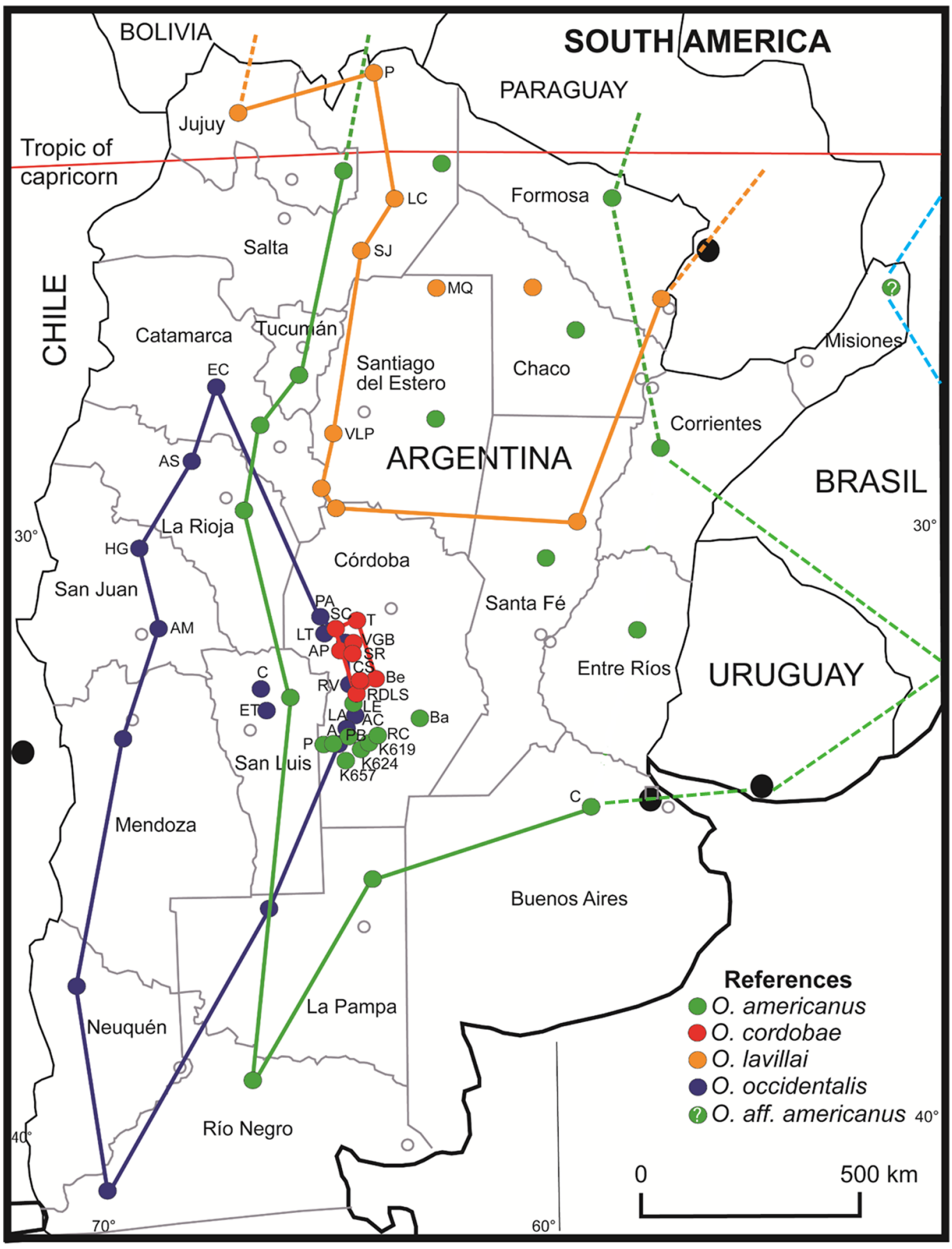

Figure 6 Geographic distribution of Odontophrynus species for eight provinces and 34 different localities sampled. Odontophrynus americanus (green label). Córdoba province (nine localities): A, Achiras; BA, Barreto; K619, Km 619, National Road \#8; K624, Km 624, National Road \#8; K657, Km 657, National Road \#8; LE, La Escondida; P, Punilla; PB, Piedra Blanca; RC, Río Cuarto. Buenos Aires province (one locality): C, Chivilcoy. O. cordobae (red label). Córdoba province (eight localities): AP, Athos Pampa; Be, Berrotarán; CS, Cañada del Sauce; RDLS, Río de los Sauces; SC, San Clemente; SR, Santa Rosa; T, Tanti; VGB, Villa General Belgrano. Note that the range extends to Bolivia, Paraguay, Uruguay and southern Brazil (dashed lines). O. lavillai (orange label). Santiago del Estero province (two localities): MQ, Monte Quemado; VLP, Villa La Punta. Salta province (three localities): LC, Los Colorados; P, Pocitos; SJ, San Javier. Note that the range extends to Bolivia and Paraguay (dashed lines). O. occidentalis (blue label). Córdoba province (seven localities): A, Achiras; AP, Alpa Corral; LA, Las 
Figure 6 (continued)

Albahacas; LT, Est. Los Tabaquillos; PA, Pampa de Achala; RV, Rodeo Viejo; VGB, Villa General Belgrano. San Luis province (two localities): C, Carolina; ET, El Trapiche. San Juan province (two localities): AM, Aguada del Molle, Sierra de Pié de Palo; HH, Huerta de Guachi. La Rioja (one locality): AS, Aguadita Springs. Catamarca province (one locality): RC, Río El Carrizal, Condor Huasi. Odontophrynus aff. americanus (pale blue label). Misiones province; probably identical with an undescribed americanus-like species from Brazil. Details on localities are given in Table S1.

Full-size $\boldsymbol{\oplus}$ DOI: 10.7717 /peerj.6480/fig-6

Zoological Nomenclature, ICZN, 1999), we consider O. barrioi a junior synonym of O. occidentalis.

In conclusion, we verify hypothesis 1 for the species of the O. americanus group, but not for the nominal taxa of the O. occidentalis group. Conflicting evidence from phenotypic and genotypic variation in the taxa of the O. occidentalis group demonstrates that adaptation to altitude and geographic isolation from conspecific populations (allopatry) may result in phenotypes that were erroneously referred to as distinct species.

Molecular evidence melts down the O. occidentalis group to single, polymorphic and highly adaptable species $O$. occidentalis.

\section{Hypothesis 2: The phenetic groups within Odontophrynus represent distinct phylogenetic lineages}

Our phylogram is formed by three clades within Odontophrynus representing the morphologically defined O. americanus, O. cultripes and O. occidentalis groups (Fig. 5). The basal splitting of lineages separates $O$. occidentalis, the only species with complex advertisement call consisting of several pulse groups, from the two lineages with simple pulsed calls. The ancestral character state of advertisement call structure in Odontophrynidae is most likely a simple pulsed call, as also present in the sister group Macrogenioglottus alipioi (Abravaya \& Jackson, 1978) and in most Proceratophrys. The species occurring in Argentina and Bolivia, the diploids O. cordobae and O. lavillai, and the topotypical tetraploids $O$. americanus are closely related, but the sister species relationship between O. americanus and O. cordobae is well resolved possibly indicating an autopolyploid origin of these tetraploids.

In conclusion, we verify hypothesis 2 with respect to the genetic base of the phenetic groups. Our reconstruction of phylogenetic relationships among these groups suggests that $O$. occidentalis evolved from the ancestral stock before the diversification of the O. americanus and O. cultripes group occurred.

\section{Hypothesis 3: The current Red List classification does not reflect the risks upon each species}

The geographical distribution of O. occidentalis is larger than previously appreciated extending to north (barrioi ecotype) and to east (achalensis ecotype) (Fig. 6).

Odontophrynus occidentalis is endemic to Argentina inhabiting many localities in eight provinces covering about $16 \%$ of the territory. This species is highly adaptable to a wide altitudinal range, and tolerant to local sympatry with O. americanus and O. cordobae. 
Thus, the Red List classification "Least Concern" seems justified, whereas the associated ecotypes "achalensis" and "barrioi" ("Vulnerable" and "Data Deficient") do not deserve classifications apart. With respect to the species referred to as O. americanus our study suggests strongly that there is more than one species involved. The nominal species O. americanus is certainly widespread in Argentina (16 provinces and ca. $67 \%$ of the territory) and extends to Bolivia and Paraguay in the north, and to Uruguay and southern Brazil in the east. The status "Least Concern" seems appropriate. The exact range of this taxon in Brazil remains to be assessed using barcoding for species identification. Most probably, the easternmost locality in Misiones pertains rather to $O$. aff. americanus 2 of Brazil than to the nominal taxon of Argentina. If this assumption proves true, the still undescribed Odontophrynus taxon would constitute the fifth species of this genus in Argentina. O. cordobae has the smallest area of distribution of the four species, occurs exclusively in the central part of the Cordoba province, and thus, is endemic to Argentina (Fig. 6). Recent assessment of localities inhabited demonstrates that there is a viable network of probably connected populations (Grenat et al., 2018). Therefore, we propose the classification "Least Concern" as long as there is no further shrinkage of its geographical range. Finally, O. lavillai inhabits eight provinces of Argentina as does O. occidentalis, but its range extends further north to Bolivia and Paraguay (Rosset \& Baldo, 2014). The classification "Least Concern" seems reasonable for this species as well. The Red List status of newly described species from Brazil and Uruguay and those of the $O$. cultripes group are outside the scope of this study.

In conclusion, we falsify hypothesis 3 with respect to genetically delimited Odontophrynus species of Argentina.

\section{CONCLUSIONS}

Integrative taxonomy has proved to be the appropriate tool to cope with distinct levels of character differentiation in the morphologically highly conserved genus of Odontophrynus toads. Genotypic variation among the nominal taxa of the O. occidentalis group did not correspond to the phenotypic plasticity in response to altitudinal and latitudinal gradients found in the ecotypes "achalensis", "barrioi" and "occidentalis". Consequently, molecular evidence melts down the O. occidentalis group to a single, polymorphic species O. occidentalis. Whereas the number of species was grossly overestimated in this case, considerable genetic divergence between $O$. americanus originating from a topotypical population (Argentina) and specimens of unknown ploidy from Brazil indicates that specimens referred to as O. americanus in Argentina and in Brazil are distinct species except for the southernmost populations in Brazil. Phylogenetic relationships among Odontophrynus species suggest that $O$. occidentalis evolved from the ancestral stock before the diversification of the $O$. americanus and $O$. cultripes group occurred. Reliable taxonomic delimitation of Odontophrynus taxa allows for a precise assessment of the corresponding geographical ranges and for an informed basis of the Red List classification. The four species occurring in Argentina do not seem endangered currently, but the small geographic range of $O$. cordobae may require a future reassessment of the species' status. 


\section{ACKNOWLEDGEMENTS}

We acknowledge the help of R. Buff, I.E. Di Tada, J.C. Acosta, E. Sanabria, J. Marinero, M. Olivares, C. Martino, P. Grenat, and J. Valetti during fieldwork, and that of B. Nilow-Lange and L. Sinsch during allozyme analyses. The manuscript benefitted from the comments of A. Fouquet, R. von May and an anonymous reviewer.

\section{ADDITIONAL INFORMATION AND DECLARATIONS}

\section{Funding}

Research was supported with grants from the German Academic Exchange Agency (DAAD: \#A/96/05802; \#A/03/22260), the Secretary Research and Technology of National University of Río Cuarto (SECyT-UNRC: \#PPI 18C/225), National Agency of Scientific and Technological Promotion (ANPCyT), and Fund for Scientific and Technological Research (FONCyT), Grant PICT 0932/2012 to Adolfo L. Martino. Ulrich Sinsch was funded by the German Academic exchange agency (DAAD: \#961 501027 3; \#961 5010065 ), and the Volkswagenstiftung (\#I/71 710). The funders had no role in study design, data collection and analysis, decision to publish, or preparation of the manuscript.

\section{Grant Disclosures}

The following grant information was disclosed by the authors:

German Academic Exchange Agency: DAAD: \#A/96/05802; \#A/03/22260.

Secretary Research and Technology of National University of Río Cuarto: SECyT-UNRC: \#PPI 18C/225.

National Agency of Scientific and Technological Promotion: ANPCyT.

Fund for Scientific and Technological Research (FONCyT): 0932/2012.

Ulrich Sinsch was funded by the German Academic exchange agency: DAAD: \#961 501 027 3; \#961 5010065.

Volkswagenstiftung: \#I/71 710.

\section{Competing Interests}

The authors declare that they have no competing interests.

\section{Author Contributions}

- Adolfo Ludovico Martino conceived and designed the experiments, performed the experiments, analyzed the data, prepared figures and/or tables, authored or reviewed drafts of the paper, approved the final draft.

- Jonas Maximilian Dehling performed the experiments, analyzed the data, prepared figures and/or tables, authored or reviewed drafts of the paper, approved the final draft.

- Ulrich Sinsch conceived and designed the experiments, performed the experiments, analyzed the data, contributed reagents/materials/analysis tools, prepared figures and/or tables, authored or reviewed drafts of the paper, approved the final draft. 


\section{Animal Ethics}

The following information was supplied relating to ethical approvals (i.e., approving body and any reference numbers):

Use of vertebrate animals was approved by the Ethics Committee (COEDI) of the Universidad Nacional de Rio Cuarto (https://www.unrc.edu.ar/unrc/coedi/index.html) (No. 38/11).

\section{Field Study Permissions}

The following information was supplied relating to field study approvals (i.e., approving body and any reference numbers):

The Córdoba Environment Agency (A.C.A.S.E.), Environmental Secretary of Córdoba Government (A01-2013), authorized our study and issued research and collecting permits.

\section{DNA Deposition}

The following information was supplied regarding the deposition of DNA sequences:

Sequences are available in GenBank. Accession numbers and details on voucher specimens used for sequencing are available in Table S3.

\section{Data Availability}

The following information was supplied regarding data availability:

The raw data are available in the Supplemental Files.

\section{Supplemental Information}

Supplemental information for this article can be found online at http://dx.doi.org/10.7717/ peer.6480\#supplemental-information.

\section{REFERENCES}

Abravaya JP, Jackson JF. 1978. Reproduction in Macrogenioglottus alipioi Carvalho (Anura, Leptodactylidae). Contributions in Science 298:1-9.

Amaro RC, Pavan D, Rodrigues MT. 2009. On the generic identity of Odontophrynus moratoi Jim \& Caramaschi, 1980 (Anura, Cycloramphidae). Zootaxa 2071:61-68.

Barrio A, Pistol de Rubel D. 1972. Encuesta cariotípica de poblaciones Argentino-Uruguayas de Odontophrynus americanus (Anura, Leptodactylidae) relacionada con otros rasgos taxonómicos. Physis 31(82):281-291.

Beçak ML. 2014. Polyploidy and epigenetic events in the evolution of Anura. Genetics and Molecular Research 13(3):5995-6014 DOI 10.4238/2014.August.7.15.

Beçak ML, Beçak W. 1974. Studies of polyploid amphibians-karyotype evolution and phylogeny of the genus Odontophrynus. Journal of Herpetology 8(4):337-341 DOI 10.2307/1562903.

Berg C. 1896. Batracios Argentinos. Enumeración sistemática, sinonímica y bibliográfica de los batracios de la Republica Argentina. Annales Museo Nacional de Historia Natural, Buenos Aires 5(2):147-226.

Borteiro C, Rosset SD, Kolenc F, Barrasso DA, Lescano JN, Baldo D. 2018. Stereotyped Defensive Behaviours in Frogs of the Genus Odontophrynus (Amphibia: Anura: Odontophrynidae). Current Herpetology 37(2):172-179 DOI 10.5358/hsj.37.172. 
Caramaschi U. 1996. Nova espécie de Odontophrynus Reinhardt \& Lütken, 1862 do Brasil Central (Amphibia, Anura, Leptodactylidae). Boletim do Museu Nacional, Nova Serie, Zoologia (Brazil) 367:1-8.

Caramaschi U, Napoli MF. 2012. Taxonomic revision of the Odontophrynus cultripes species group, with description of a new related species (Anura, Cycloramphidae). Zootaxa 3155(3155):1-20.

Cei JM. 1985. Un nuevo y peculiar Odontophrynus de la sierra de Guasayan, Santiago del Estero, Argentina (Anura, Leptodactylidae). Cuadernos de Herpetologia 1:1-13.

Cei JM. 1987. Additional notes to "Amphibians of Argentina": An update 1980-1986. Monitore zoologico italiano, NS 21:209-272.

Cei JM, Crespo EG. 1982. Differences in larval morphology of allopatric isolated populations of the Odontophrynus occidentalis group from western Argentina. Arquivos do Museo Bocage 1:335-340.

Cei JM, Ruiz IRG, Beçak W. 1982. Odontophrynus barrioi, a new species of anuran from Argentina. Journal of Herpetology 16(2):97-102 DOI 10.2307/1563800.

Crespo E, Cei J. 1983. Osteological differences in allopatric populations of the Odontophrynus occidentalis group from western Argentina. Arquivos do Museu Bocage, Série B 2:47-55.

Darriba D, Taboada GL, Doallo R, Posada D. 2012. jModelTest 2: more models, new heuristics and high-performance computing. Nature Methods 9(8):772-772 DOI 10.1038/nmeth.2109.

Dayrat B. 2005. Towards integrative taxonomy. Biological Journal of the Linnean Society 85(3):407-415 DOI 10.1111/j.1095-8312.2005.00503.x.

De Magalhães RF, Rocha PC, Santos FR, Strussmann C, Giaretta AA. 2018. Integrative taxonomy helps to assess the extinction risk of anuran species. Journal for Nature Conservation 45:1-10 DOI 10.1016/j.jnc.2018.07.001.

Dias PHDS, Amaro RC, De Carvalho-E-Silva AMPT, Rodrigues MT. 2013. Two new species of Proceratophrys Miranda-Ribeiro, 1920 (Anura; Odontophrynidae) from the Atlantic forest, with taxonomic remarks on the genus. Zootaxa 3682(2):277-304 DOI 10.11646/zootaxa.3682.2.5.

Di Tada IE, Barla MJ, Martori RA, Cei JM. 1984. Odontophrynus achalensis una nueva especie de anfibio de la Pampa de Achala (Córdoba, Argentina). Historia Natural 4(17):149-155.

Do Nascimento FAC, Mott T, Langone JA, Davis CA, De Sa RO. 2013. The genus Odontophrynus (Anura: Odontophrynidae): a larval perspective. Zootaxa 3700(1):140-158 DOI 10.11646/zootaxa.3700.1.5.

Duméril AMC, Bibron G. 1841. Erpétologie générale ou histoire naturelle compléte de reptiles. Paris: Roret.

D’Orbigny A. 1847. Voyage dans l'Amérique méridionale: (le Brésil, la république orientale de l'Uruguay, la République argentine, la Patagonie, la république du Chili, la république de Bolivia, la république du Pérou), exécuté pendant les années 1826, 1827, 1828, 1829, 1830, 1831, 1832, et 1833 (1835). Paris: Bertrand.

Edgar RC. 2004. MUSCLE: multiple sequence alignment with high accuracy and high throughput. Nucleic Acids Research 32(5):1792-1797 DOI 10.1093/nar/gkh340.

Elmer KR, Dávila JA, Lougheed SC. 2007. Cryptic diversity and deep divergence in an upper Amazonian leaflitter frog, Eleutherodactylus ockendeni. BMC Evolutionary Biology 7(1):247 DOI 10.1186/1471-2148-7-247.

Felsenstein J. 2008. PHYLIP (Phylogeny Inference Package). Version 3.695. Seattle: University of Washington. Available at http://evolution.genetics.washington.edu/phylip.html. Distributed by the author. Department of Genome Sciences. 
Feng YJ, Blackburn DC, Liang D, Hillis DM, Wake DB, Cannatella DC, Zhang P. 2017. Phylogenomics reveals rapid, simultaneous diversification of three major clades of Gondwanan frogs at the Cretaceous-Paleogene boundary. Proceedings of the National Academy of Sciences of the United State of America 114(29):E5864-E5870 DOI 10.1073/pnas.1704632114.

Fouquet A, Vacher JP, Courtois EA, Villette B, Reizine H, Gaucher P, Jairam R, Ouboter P, Kok P Jr. 2018. On the brink of extinction: two new species of Anomaloglossus from French Guiana and amended definitions of Anomaloglossus degranvillei and A. surinamensis (Anura: Aromobatidae). Zootaxa 4379(1):1-23 DOI 10.11646/zootaxa.4379.1.1.

Frost DR. 2018. Amphibian species of the world: an online reference. New York: American Museum of Natural History. Available at http://research.amnh.org/herpetology/amphibia/index.html (accessed 11 November 2018).

González E, Galvani G, Sanabria E, Barrasso DA, Alcalde L, Quiroga L. 2014. The tadpole of Odontophrynus barrioi Cei, Ruiz, and Beçak, 1982 (Anura: Odontophrynidae): a comparison with the other tadpoles of the genus. Acta Herpetologica 9:15-23.

Grenat P, Salas N, Martino A. 2009. Erythrocyte size as diagnostic character for the identification of live cryptic Odontophrynus americanus and O. cordobae (Anura: Cycloramphidae). Zootaxa 2049:67-68.

Grenat P, Salas N, Pollo F, Otero M, Baraquet M, Sinsch U, Martino A. 2018. Naturally occurring triploids in contact zones between diploid/tetraploid closely related species Odontophrynus cordobae and O. americanus (Anura, Cycloramphidae). Amphibia-Reptilia 39(1):1-10 DOI 10.1163/15685381-00003141.

Hebert PDN, Beaton MJ. 1993. Methodologies for allozyme analysis using cellulose acetate electrophoresis. Second Edition. Beaumont: Helena Laboratories.

Highton R. 1999. Geographic protein variation and speciation in the salamanders of the Plethodon cinereus group with the description of two new species. Herpetologica 55:43-90.

International Commission on Zoological Nomenclature, ICZN. 1999. International code of zoological nomenclature. Fourth Edition. London: International Trust for Zoological Nomenclature, i-xxix + 1-306.

IUCN. 2018. The IUCN Red List of Threatened Species. Version 2018-1. Available at www.iucnredlist.org (accessed 11 August 2018).

Kaefer IL, Tsuji-Nishikido BM, Mota EP, Farias IP, Lima AP. 2013. The early stages of speciation in amazonian forest frogs: phenotypic conservatism despite strong genetic structure. Evolutionary Biology 40(2):228-245 DOI 10.1007/s11692-012-9205-4.

Köhler J, Jansen M, Rodríguez A, Kok PJR, Toledo LF, Emmrich M, Glaw F, Haddad CFB, Rödel M-O, Vences M. 2017. The use of bioacoustics in anuran taxonomy: theory, terminology, methods and recommendations for best practice. Zootaxa 4251(1):124 DOI 10.11646/zootaxa.4251.1.1.

Kumar S, Stecher G, Tamura K. 2016. MEGA7: molecular evolutionary genetics analysis Version 7.0 for bigger datasets. Molecular Biology and Evolution 33(7):1870-1874 DOI 10.1093/molbev/msw054.

Larget B, Simon DL. 1999. Markov chasin monte carlo algorithms for the bayesian analysis of phylogenetic trees. Molecular Biology and Evolution 16(6):750-759 DOI 10.1093/oxfordjournals.molbev.a026160.

Lescure J, Bour R, Ineich I, Ohler AM, Ortiz JC. 2002. Liste inédite des Reptiles et Amphibiens récoltés par Alcide d'Orbigny en Amérique méridionale. Comptes Rendus Palevol

1(2002):527-532. 
Lyra ML, Haddad CFB, De Azeredo-Espin AML. 2017. Meeting the challenge of DNA barcoding Neotropical amphibians: polymerase chain reaction optimization and new COI primers. Molecular Ecology Resources 17(5):966-980 DOI 10.1111/1755-0998.12648.

Martino AL, Sinsch U. 2002. Speciation by polyploidy in Odontophrynus americanus. Journal of Zoology 257(1):67-81 DOI 10.1017/S0952836902000663.

Murphy RW, Sites JW, Buth DG, Haufler CH. 1996. Proteins: isozyme electrophoresis. In: Hillis DM, Moritz C, Mable BK, eds. Molecular Systematics. Second Edition. Sunderland: Sinauer Associates, 51-120.

Nei M. 1972. Genetic distance between populations. American Naturalist 106(949):283-292 DOI 10.1086/282771.

Padial JM, De La Riva I. 2010. A response to recent proposals for integrative taxonomy. Biological Journal of the Linnean Society 101(3):747-756 DOI 10.1111/j.1095-8312.2010.01528.x.

Padial JM, Miralles A, De la Riva I, Vences M. 2010. The integrative future of taxonomy. Frontiers in Zoology 7(1):16 DOI 10.1186/1742-9994-7-16.

Palumbi S. 1996. Nucleic acids II: the polymerase chain reaction. In: Hillis DM, Moritz C, Mable BK, eds. Molecular Systematics. Sunderland: Sinauer Associates, 205-247.

Pyron RA, Wiens JJ. 2011. A large-scale phylogeny of Amphibia including over 2800 species, and a revised classification of extant frogs, salamanders, and caecilians. Molecular Phylogenetics and Evolution 61(2):543-583 DOI 10.1016/j.ympev.2011.06.012.

Rakotoarison A, Glaw F, Vieites DR, Raminosoa NR, Vences M. 2012. Taxonomy and natural history of arboreal microhylid frogs (Platypelis) from the Tsaratanana Massif in northern Madagascar, with description of a new species. Zootaxa 3563(3563):1-25.

Rocha PC, De Sena LMF, Pezzuti TL, Leite FSF, Svartman M, Rosset SD, Baldo D, Garcia PCD. 2017. A new diploid species belonging to the Odontophrynus americanus species group (Anura: Odontophrynidae) from the Espinhaco range, Brazil. Zootaxa 4329(4):327-350 DOI 10.11646/zootaxa.4329.4.2.

Rojas RR, Chaparro JC, De Carvalho VT, Avila RW, Farias IP, Hrbek T, Gordo M. 2016. Uncovering the diversity in the Amazophrynella minuta complex: integrative taxonomy reveals a new species of Amazophrynella (Anura, Bufonidae) from southern Peru. Zookeys 563:43-71 DOI 10.3897/zookeys.563.6084.

Rojas RR, Fouquet A, Ron SR, Hernández-Ruz EJ, Melo-Sampaio PR, Chaparro JC, Vogt RC, Carvalho VTd, Pinheiro LC, Avila RW, Farias IP, Gordo M, Hrbek T. 2018.

A Pan-Amazonian species delimitation: high species diversity within the genus Amazophrynella (Anura: Bufonidae). PeerJ 6:e4941 DOI 10.7717/peerj.4941.

Ronquist F, Teslenko M, Van Der Mark P, Ayres DL, Darling A, Hohna S, Larget B, Liu L, Suchard MA, Huelsenbeck JP. 2012. MrBayes 3.2: efficient Bayesian Phylogenetic inference and model choice across a large model space. Systematic Biology 61(3):539-542

DOI 10.1093/sysbio/sys029.

Rosset SD. 2008. New species of Odontophrynus Reinhardt and Lütken 1862 (Anura: Neobatrachia) from Brazil and Uruguay. Journal of Herpetology 42(1):134-144 DOI 10.1670/07-088R1.1.

Rosset S, Baldo D. 2014. The advertisement call and geographic distribution of Odontophrynus lavillai Cei, 1985 (Anura: Odontophrynidae). Zootaxa 3784(1):79-83 DOI 10.11646/zootaxa.3784.1.5.

Rosset SD, Baldo D, Lanzone C, Basso NG. 2006. Review of the geographic distribution of diploid and tetraploid populations of the Odontophrynus americanus species complex 
(Anura: Leptodactylidae). Journal of Herpetology 40(4):465-477

DOI 10.1670/0022-1511(2006)40[465:rotgdo]2.0.co;2.

Rosset SD, Ferraro PJ, Alcalde L, Basso NG. 2007. A revison of Odontophrynus barrioi (Anura: Neobatrachia): morphology, osteology, vocalizations, and geographic distribution. South American Journal of Herpetology 2(2):97-106 DOI 10.2994/1808-9798(2007)2[97:arooba]2.0.co;2.

Ruiz IRG, Cei JM, Beçak W. 1982. Chromosomal evolution in allopatric populations of the Odontophrynus occidentalis group (Amphibia, Anura) from western Argentina. Cytogenetic and Genome Research 33(4):303-311 DOI 10.1159/000131776.

Sáez PA, Fibla P, Correa C, Sallaberry M, Salinas H, Veloso A, Mella J, Iturra P, Méndez MA. 2014. A new endemic lineage of the Andean frog genus Telmatobius (Anura, Telmatobiidae) from the western slopes of the central Andes. Zoological Journal of the Linnean Society 171(4):769-782 DOI 10.1111/zoj.12152.

Salas NE, Di Tada IE. 1994. Análisis bioacústico del canto nupcial de Odontophrynus occidentalis y Odontophrynus achalensis (Anura: Leptodactylidae) en la Provincia de Córdoba. Revista Universidad Nacional Rio Cuarto 14:55-63.

Salas NE, Martino AL. 2007. Cariotipo de Odontophrynus cordobae Martino \& Sinsch, 2002 (Anura, Leptodactylidae). BAG Journal of basic and applied genetics 18:1-5.

Salas NE, Steinlein C, Schmid M. 2000. Karyotype of Odontophrynus achalensis (Anura, Leptodactylidae). Amphibia-Reptilia 21(4):495-498.

Santos-Silva DL, Andrade SP, Rocha CF, Maciel NM, Caramaschi U, Vaz-Silva W. 2017. Redescription of the tadpole of Odontophrynus carvalhoi Savage and Cei, 1965 (Anura, Odontophrynidae) with comments on the geographical distribution of the species. Zootaxa 4323(3):419-422 DOI 10.11646/zootaxa.4323.3.7.

Schneider H, Sinsch U. 2007. Contributions of bioacoustics to the taxonomy of Anura. In: Heatwole H, Tyler MJ, eds. Amphibian Biology-Phylogeny and Systematics. Shipping Norton: Surrey Beatty \& Sons, 2893-2932.

Scillitani G, Picariello O. 2000. Genetic variation and its causes in the Crested Newt, Triturus carnifex (Laurenti, 1768), from Italy (Caudata: Salamandridae). Herpetologica 56:119-130.

Sinsch U, Pelster B, Ludwig G. 2015. Large-scale variation of size- and age-related life-history traits in the common frog: a sensitive test case for macroecological rules. Journal of Zoology 297(1):32-43 DOI 10.1111/jzo.12243.

Sukumaran J, Knowles LL. 2017. Multispecies coalescent delimits structure, not species. Proceedings of the National Academy of Sciences of the United States of America 114(7):1607-1612 DOI 10.1073/pnas.1607921114.

Stuart SN, Chanson JS, Cox NA, Young BE, Rodrigues ASL, Fischman DL, Waller RW. 2004. Status and trends of amphibian declines and extinctions worldwide. Science 306(5702):1783-1786 DOI 10.1126/science.1103538.

Turazzini GF, Taglioretti ML, Gomez RO. 2016. First fossil record of the South American frog genus Odontophrynus Reinhardt and Lütken, 1862 (Anura, Neobatrachia). Journal of Vertebrate Paleontology 36(6):e1228657 DOI 10.1080/02724634.2017.1228657.

Vacher J-P, Kok PJR, Rodrigues MT, Lima JD, Lorenzini A, Martinez Q, Fallet M, Courtois EA, Blanc M, Gaucher P, Dewynter M, Jairam R, Ouboter P, Thébaud C, Fouquet A. 2017. Cryptic diversity in Amazonian frogs: integrative taxonomy of the genus Anomaloglossus (Amphibia: Anura: Aromobatidae) reveals a unique case of diversification within the Guiana Shield. Molecular Phylogenetics and Evolution 112:158-173

DOI 10.1016/j.ympev.2017.04.017. 
Van Buskirk J. 2009. Natural variation in morphology of larval amphibians: phenotypic plasticity in nature? Ecological Monographs 79(4):681-705 DOI 10.1890/08-1692.1.

Vences M, Köhler J, Crottini A, Glaw F. 2010. High mitochondrial sequence divergence meets morphological and bioacoustic conservatism: Boophis quasiboehmei sp. n., a new cryptic treefrog species from south-eastern Madagascar. Bonn Zoological Bulletin 57:241-255.

Vences M, Thomas M, Van Der Meijden A, Chiari Y, Vieites DR. 2005. Comparative performance of the 16S rRNA gene in DNA barcoding of amphibians. Frontiers in Zoology 2(1):5 DOI 10.1186/1742-9994-2-5.

Vieites DR, Wollenberg KC, Andreone F, Köhler J, Glaw F, Vences M. 2009. Vast underestimation of Madagascar's biodiversity evidenced by an integrative amphibian inventory. Proceedings of the National Academy of Sciences of the United States of America 106(20):8267-8272 DOI 10.1073/pnas.0810821106.

Von May R, Lehr E, Rabosky DL. 2018. Evolutionary radiation of earless frogs in the Andes: molecular phylogenetics and habitat shifts in high-elevation terrestrial breeding frogs. PeerJ 6:e4313 DOI 10.7717/peerj.4313.

Winter M, Fiedler W, Hochachka WM, Koehncke A, Meiri S, De la Riva I. 2016. Patterns and biases in climate change research on amphibians and reptiles: a systematic review. Royal Society Open Science 3(9):160158 DOI 10.1098/rsos.160158.

Zhang P, Liang D, Mao R-L, Hillis DM, Wake DB, Cannatella DC. 2013. Efficient sequencing of Anuran mtDNAs and a Mitogenomic exploration of the Phylogeny and evolution of Frogs. Molecular Biology and Evolution 30(8):1899-1915

DOI 10.1093/molbev/mst091.

\section{FURTHER READING}

Darst CR, Cannatella DC. 2004. Novel relationships among hyloid frogs inferred from $12 \mathrm{~S}$ and $16 \mathrm{~S}$ mitochondrial DNA sequences. Molecular Phylogenetics and Evolution 31(2):462-475 DOI 10.1016/j.ympev.2003.09.003.

Faivovich J, Ferraro DP, Basso NG, Haddad CFB, Rodrigues MT, Wheeler WC, Lavilla EO. 2012. A phylogenetic analysis of Pleurodema (Anura: Leptodactylidae: Leiuperinae) based on mitochondrial and nuclear gene sequences, with comments on the evolution of anuran foam nests. Cladistics 28(5):460-482 DOI 10.1111/j.1096-0031.2012.00406.x.

Faivovich J, Haddad CFB, Garcia PCA, Frost DR, Campbell JA, Wheeler WC. 2005. Systematic review of the frog family Hylidae, with special reference to Hylinae: phylogenetic analysis and taxonomic revision. Bulletin of the American Museum of Natural History 294(1):6-228

Faivovich J, Nicoli L, Blotto BL, Pereyra MO, Baldo D, Barrionuevo JS, Fabrezi M, Wild ER, Haddad CFB. 2014. Big, bad, and beautiful: phylogenetic relationships of the horned frogs (Anura: Ceratophryidae). South American Journal of Herpetology 9(3):207-227 DOI 10.2994/SAJH-D-14-00032.1.

Fouquet A, Leonardo Blotto B, Maronna MM, Verdade VK, Junca FA, De Sa R, Rodrigues MT. 2013. Unexpected phylogenetic positions of the genera Rupirana and Crossodactylodes reveal insights into the biogeography and reproductive evolution of leptodactylid frogs. Molecular Phylogenetics and Evolution 67(2):445-457 DOI 10.1016/j.ympev.2013.02.009.

Frost DR, Grant T, Faivovich J, Bain RH, Haas A, Haddad CFB, De Sa RO, Channing A, Wilkinson M, Donnellan SC, Raxworthy CJ, Campbell JA, Blotto BL, Moler P, Drewes RC, 
Nussbaum RA, Lynch JD, Green DM, Wheeler WC. 2006. The amphibian tree of life. Bulletin of the American Museum of Natural History 297:1-291.

Teixeira M, Amaro RC, Recoder RS, Dal Vechio F, Rodrigues MT. 2012. A new dwarf species of Proceratophrys Miranda-Ribeiro, 1920 (Anura, Cycloramphidae) from the highlands of Chapada Diamantina, Bahia, Brazil. Zootaxa 3551:25-42.

Van Bocxlaer I, Biju SD, Loader SP, Bossuyt F. 2009. Toad radiation reveals into-India dispersal as a source of endemism in the Western Ghats-Sri Lanka biodiversity hotspot. BMC Evolutionary Biology 9(1):131 DOI 10.1186/1471-2148-9-131. 